\title{
THE SQUEAL RULE: STATUTORY RESOLUTION AND CONSTITUTIONAL IMPLICATIONS-BURDENING THE MINOR'S RIGHT OF PRIVACY
}

Since 1942 the United States Supreme Court has on several occasions considered individual rights related to sexual activity, and the extent to which the government permissibly may infringe these rights. ${ }^{1}$ The individual's rights to make personal decisions regarding abortion and contraception free from governmental intrusion derive from a broader and more fundamental right of privacy ${ }^{2}$ that the Court consistently has recognized in these contexts. Concurrently, lawmakers have enacted various statutes designed to increase parental authority ${ }^{3}$ and curb sexual autonomy, ${ }^{4}$ in an attempt to uphold traditional sexual

1. See, e.g., H.L. v. Matheson, 450 U.S. 398 (1981) (upholding state law requiring parental notification before performing abortion on a minor); Bellotti v. Baird, 443 U.S. 622 (1979) (finding constitutionally invalid a state law requiring parental consent for any nonemergency abortion unless no parent available); Carey v. Population Servs. Int'l, 431 U.S. 678 (1977) (holding unconstitutional a state law criminalizing the distribution of nonprescription contraceptives to minors); Planned Parenthood v. Danforth, 428 U.S. 52 (1976) (upholding state law requiring parental consent for abortion performed on a minor); Roe v. Wade, 410 U.S. 113 (1973) (holding unconstitutional state criminal abortion statutes prohibiting abortion at any stage of pregnancy); Eisenstadt v. Baird, 405 U.S. 438 (1972) (state law prohibiting distribution of contraceptives to unmarried persons held to violate equal protection clause); Griswold v. Connecticut, 381 U.S. 479 (1965) (state law forbidding use of contraceptives by married persons held to violate right of marital privacy); Skinner $v$. Oklahoma, 316 U.S. 535 (1942) (invalidating, under the equal protection clause, a state statute which provided that a criminal offender should be sterilized upon a third conviction of felony involving moral turpitude).

2. The evolution and scope of the right of privacy is discussed infra at text accompanying notes 68-84. The term "right of privacy" will be used throughout this note to refer to decisions relating to sexual privacy, including the freedom to make personal choices regarding contraception, procreation, abortion, marriage, and sexual activity.

3. See, e.g., ILl. ANN. STat. ch. 38, If 81-51 (Smith-Hurd Supp. 1984) (parental consent required for unmarried minor seeking abortion); ILL. ANN. STAT. ch. 38, ๆ 81-64 (Smith-Hurd Supp. 1984) (24 hours notice given to parents of unmarried minor seeking abortion); MASS. ANN. LAws ch. 112, § 12S (Michie/Law Co-op. Supp. 1984) (parental consent required for unmarried minor seeking abortion); N. C. GEN. STAT. §115C-378 (Supp. 1981) (parent empowered with authority to require compulsory school attendance of minor child; parental notification required in event of excessive school absences); N.D. CENT. CODE ANN. § 14-02.1-03.1 (1981) (unmarried pregnant minor seeking abortion requires parental consent); R.I. GEN. LAws $\S 23$ - 4.7-6 (Supp. 1984) (parental consent required for unmarried minor seeking abortion); UTAH CODE ANN. $\$ 76-7$ 304 (1978 replacement) (physician must notify parents of minor seeking abortion).

4. See, e.g., ILl. ANN. STAT. ch. 38, § 11-8 (Smith-Hurd 1979) (criminalizing "open and notorious" cohabitation or sexual intercourse by unmarried persons); N.C. GEN. STAT. \$ 14-177 
values. In response, the Supreme Court has struggled during the last decade to carve out a standard for parental consent and notification that reflects the delicate balance between the values of parental guidance and the minor's fundamental right of privacy. ${ }^{5}$

On January 26, 1983, the Department of Health and Human Services (DHHS) promulgated regulations mandating parental notification for unemancipated minors who seek prescription contraceptives from federally funded family planning clinics. ${ }^{6}$ Popularly

(1981) (criminalizing "the crime against nature"-defined by caselaw as oral or anal sexual activity — by any persons); N.C. GEN. STAT. § 14-184 (1981) (criminalizing cohabitation and "lewd and lascivious associat[ion]" by unmarried persons); N.D. CENT. CODE § 12.1-20-08 (1981) (criminalizing any sexual contact by a minor); N.D. CENT. CODE 12.1-20-10 (1981) (criminalizing cohabitation "as a married couple" by unmarried persons); N.D. CENT. CODE § 12.1-20-02, -20 (1981) (criminalizing sexual contact with an "animal, bird, or dead person"); UTAH CODE ANN. § 76-5-403 (1978 replacement) (criminalizing oral or anal sex between persons, regardless of agc or sex); UTAH CODE ANN. § 76-7-104 (1978 replacement) (criminalizing sexual intercourse between unmarried persons).

5. See supra note 1.

6. In addition to redefining requirements of economic needs, the regulations amend 42 C.F.R.

Part 59 as follows:

42 C.F.R. 59.5 is amended by adding thereto the following paragraph (a)(12), to read as follows:

$\$ 59.5$ What requirements must be met by a family planning project?

(a)***

(12) Encourage, to the extent practical, family participation in the provision of the project's services to unemancipated minors. Notwithstanding any other requirement of this subpart, a project shall,

(i)(A) When prescription drugs or prescription devices are initially provided by the project to an unemancipated minor, notify a parent or guardian that they were provided, within 10 working days following their provision. The project must tell the minor prior to the provision of services about this notification requirement. As used in this subsection, the phrase "parent or guardian" shall refer to a parent or guardian residing with the minor or otherwise exercising parental functions with respect to the minor. The project shall verify by certified mail (with restricted delivery and return receipt requested), or other similar form of documentation, that the notification has been received. Where the project is unablc to verify that notification was received, the project shall not provide additional prescription drugs or devices to the minor.

(B) A project is not required to comply with paragraph (a)(12)(i)(A) of this section where the project director or clinic head (when specifically so designated by the project director) determines that notification will result in physical harm to the minor by a parent or guardian.

(C) For the purposes of this paragraph (a)(12)(i), an "unemancipated minor" is an individual who is age 17 or under and is not, with respect to factors other than age, emancipated under State law.

(D) The project must keep records of notifications provided pursuant to the first sentence of paragraph $(a)(12)(i)(A)$ of this section, and of verification that thosc notifications were received. The project must also keep records of the number of determinations madc under paragraph $(a)(12)(i)(B)$ of this section and the factual basis for such determinations. The project must make records required by this subparagraph available to the Secretary on request.

(E) This paragraph (a)(12)(i) of this section does not apply where prescription drugs are provided for the treatment of sexually transmitted diseases.

(ii) Where State law requires the notification or consent of a parent or guardian to the provision of family planning services to an individual who is an unemancipated minor under State law, provide such services only in the compliance with such law. 
known as the "squeal rule,"7 the regulation was designed to promote parental involvement in the minor's contraceptive decision. ${ }^{8}$

This note considers the validity of the "squeal rule" from both a legislative and a constitutional perspective. Part I outlines the statutory authority and legislative history underlying the rule as well as the recent cases concluding that it contravenes congressional intent. 9 Because future notification provisions may be upheld if promulgated under new or different statutory authority, Part II considers whether the rule places an unconstitutional burden ${ }^{10}$ on the exercise of a minor's right of privacy, and analyzes state interests in protecting the child, ${ }^{11}$ cultivating parental involvement, ${ }^{12}$ promoting morality, ${ }_{13}^{13}$ protecting the health of the minor, ${ }^{14}$ and allocating scarce financial resources. ${ }^{15}$ The note concludes that the "squeal rule" unconstitutionally burdens the right of privacy of mature minors who are capable of making intelligent contraception decisions on their own.

\section{Congressional Policy and the DHHS Regulation}

On January 26, 1983, the DHHS, pursuant to its authority under Title X of the Public Health Service Act, ${ }^{16}$ amended the regulations governing the family planning services program. ${ }^{17}$ The new rules, which have generated "a great whirlwind of public controversy,"18 contain three main provisions: (1) federally funded family planning facilities must notify the parent or guardian of an unemancipated minor receiving prescription contraceptives ${ }^{19}$ within ten days of their provision; ${ }^{20}(2)$ the

7. See, e.g., Kiss and Tell-Squeal Rule Enjoined, 69 A.B.A. J. 829 (1983). Although the term "squeal rule" technically applies only to the notification portion of the regulation, it is commonly used to refer to the regulation as a whole. This note generally will use the term "squeal rule" interchangeably with "the DHHS regulation" to refer to the entire regulation. The context should make clear when it is used to refer only to the notification portion of the rule.

8. See 48 Fed. Reg. 3602 (1983).

9. See infra notes $16-63$ and accompanying text.

10. See infra notes $64-115$ and accompanying text.

11. See infra notes $116-42$ and accompanying text.

12. See infra notes $143-54$ and accompanying text.

13. See infra notes $155-61$ and accompanying text.

14. See infra notes $162-72$ and accompanying text.

15. See infra notes $173-78$ and accompanying text.

16. 42 U.S.C. $\$ \S 300$ et seq. (1982).

17. Grants for Family Planning Services, 42 C.F.R. $\$ \S 59.2$, 59.5(a)(12)(i), (ii) (1983).

18. Planned Parenthood Fed'n of America v. Heckler, 712 F.2d 650, 665 (D.C. Cir. 1983).

19. The rule specifically applies to "prescription drugs or prescription devices," 42 C.F.R. $\S 59.5(\mathrm{a})(12)(\mathrm{i})(\mathrm{A})(1983)$, which include the pill, the IUD, and the diaphragm. Other methods of contraception, including condoms, and spermicides, may be obtained over-the-counter and are not subject to the notification requirement. 49 Fed. Reg. 3600,3609 (1983).

20. The minor must be advised of this notification requirement before the provision of services. 42 CFR $\$ 59.5(a)(12)(i)(A)(1983)$. The regulation contains two limited exceptions: notification is 
facilities must comply with any existing state laws requiring parental notification or consent for the provision of contraceptive services to minors; ${ }^{21}$ and (3) in order to satisfy the low-income test for eligibility to receive services on a confidential basis, minors must now be evaluated on the basis of their parents' resources. ${ }^{22}$

Even before the regulation was published in final form, institutional family planning recipients of Title $\mathrm{X}$ funds filed actions in federal district courts in four states to enjoin its enforcement. ${ }^{23}$ On February 8, 1983, federal courts in New York and the District of Columbia enjoined enforcement of the regulation on the ground that it was promulgated in excess of DHHS' delegated authority. ${ }^{24}$ The courts reasoned that by mandating rather than merely encouraging family involvement, the regulation contravened the clear congressional intent underlying Title $\mathrm{X}$ to halt the epidemic of teenage pregnancies. ${ }^{25}$

not required if the project director determines that "notification will result in physical harm to the minor by a parent or guardian," 42 C.F.R. $\S 59.5(a)(12)(\mathrm{i})(\mathrm{B})$ (1983); and "prescription drugs provided for the treatment of sexually-transmitted diseases" are not subject to the regulation, 42 C.F.R. $\S 59.5(\mathrm{a})(12)(\mathrm{i})(\mathrm{E})(1983)$.

21. 42 C.F.R. $\$ 59.5(a)(12)(i)(E)(i i)$ (1983). As of June 1983, Utah was the only state with sueh a consent and notification statute. ALAN GUTTMACHER INST., MAKING Choices: Evaluating tHe HEALTH RISKS AND BENEFits OF BIRTH Control MEthods 26-27 (1983). In December 1983, a federal district court invalidated that statute on the alternative grounds that Title $\mathrm{X}$ preempts it, and that the statute would permit an unconstitutional invasion of the privacy right to decide whether to bear or beget children. Planned Parenthood Ass'n v. Matheson, 582 F. Supp. 1001, 1006, 1009 (D. Utah 1983) (discussed infra notes 32, 61).

22. The regulation repealed the following sentence from DHHS' definition of 'low-income family" for the purposes of family planning projects: "For example, unemancipated minors who wish to receive services on a confidential basis must be considered on the basis of their own resources." 42 C.F.R. $\S 59.2$ (1982). Title X regulations define a "low-income family" as "a family whose total annual income does not exceed 100 percent of the most recent Community Services Administration Income Poverty Guidelines." 42 C.F.R. § 59.2 (1983).

23. Planned Parenthood Fed'n v. Schweiker, 559 F. Supp. 658 (D.D.C.), aff'd sub nom. Planned Parenthood Fed'n v. Heckler, 712 F.2d 650 (D.C. Cir. 1983); New York v. Schweiker, 557 F. Supp. 354 (S.D.N.Y. 1983) (preliminary injunction issued), permanent injunction issued without published opinion, Nos. 83 Civ. 0726, 0727 (S.D.N.Y. Mar. 14, 1983) (available Dec. 31, 1984 on LEXIS Genfed library, Dist file), aff'd sub nom. New York v. Heckler, 719 F.2d 1191 (2d Cir. 1983); Memphis Ass'n of Planned Parenthood v. Schweiker, No. 83-2060 (W.D. Tenn. Jan. 24, 1983) (order granting preliminary injunction); Vincent v. Schweiker, No. 83-1110-P (D. W. Va. Jan. 24, 1983) (order granting preliminary injunction) (cited in Brief for Appellee Planned Parenthood at 2, Planned Parenthood Fed'n v. Heckler, 712 F.2d 650 (D.C. Cir. 1983)).

24. New York v. Schweiker, 557 F. Supp. 354, 359-62 (S.D.N.Y. 1983) (preliminary injunction); Planned Parenthood Fed'n v. Schweiker, 559 F. Supp. 658 (D.D.C.) (permanent injunction), aff' sub nom. Planned Parenthood Fed'n v. Heckler, 712 F.2d 650 (D.C. Cir. 1983). The Tennessee district court issued a cursory injunction, noting its reliance on the rationale of these two opinions. Memphis Ass'n of Planned Parenthood v. Schweiker, No. 83-2060 (W.D. Tenn. 1983).

25. New York v. Schweiker, 557 F. Supp. at 359-62; Planned Parenthood Fed'n v. Schweiker, 559 F. Supp. at 665-69. To be valid, agency action must be consistent with the congressional purpose underlying the authorizing statute. See Batterton v. Franeis, 432 U.S. 416, 424-26 (1977). 


\section{A. Title $X$.}

In 1970 , Congress created Title $X^{26}$ to establish a system of federally funded public and nonprofit-private family planning projects providing a broad range of family planning services. ${ }^{27}$ Title $X$ grantees provided services to teenagers from the inception of the program. ${ }^{28}$ Yet, because of the increasing pregnancy rate among this group throughout the 1970's, Congress became concerned that the original Title X program was inadequate to meet the contraceptive needs of sexually active teenagers. ${ }^{29}$ Responding to the argument that the "virtual epidemic of teenage pregnancies require[d] emergency measures" targeted specifically at adolescents, ${ }^{30}$ Congress amended Title $X$ in 1978 to include language clarifying its intent that Title $X$ projects provide "services for adolescents." 31 Congress thus intended the program "to assist sexually active adolescents to avoid unwanted pregnancies." 32

\footnotetext{
26. Pub. L. No. 91-572, 84 Stat. 1504 (1970).

27. 42 U.S.C. $\S 300$ (1982).

28. See 42 C.F.R. $\$ 59.5(a)(4)(1981)$ (Title $X$ services were to be provided "without regard to ... age, sex, . . or marital status.") (emphasis added).
}

29. See, e.g., H.R. REP. No. 1161, 93d Cong., 2d Sess. 14 (1974) ("certain population groups requiring these services are not being reached ... includ[ing] teenagers").

30. Brief for Appellee, National Family Planning \& Reproductive Health Association (NFPRHA) at 10, Planned Parenthood Fed'n v. Heckler, 712 F.2d 650 (D.C. Cir. 1983) [hereinafter cited as Brief for NFPRHA].

31. 42 U.S.C. $\$ 300$ (a) (1982).

32. S. Rep. No. 822, 95th Cong., 2d Sess. 31 (1978) ("The Committee is convinced that existing family planning programs' efforts to reach adolescents must be maintained and that special efforts must be made to expand these efforts.").

Proponents of the campaign to encourage teenagers' use of Title X's contraceptive services carefully stated that the new provision "should not be construed as condoning adolescent sexual activity. Rather, [the 1978 amendment] deals with reality and simply attempts to provide young people with the information necessary to avoid pregnancy." 124 Cong. Rec. 31,248 (1978) (statement of Rep. Whaler).

Consistent with Title X, the Aid to Families with Dependent Children (AFDC) Program and the Medicaid Program of the Social Security Act require participating states to furnish prompt family planning "services and supplies" to sexually active minors. The AFDC program requires state plans to

provide ... for the development of a program, . . . for preventing or reducing the incidence of births out of wedlock and otherwise strengthening family life, and for implementing such program by assuring that in all appropriate cases (including minors who can be considered to be sexually active) family planning services are offered to them and are provided promptly . . . .

42 U.S.C. $\S 602(a)(15)(A)(1982)$.

The Medicaid Program of the Social Security Act defines "medieal assistance" as payment of part or all of the costs of . . . family planning services and supplies furnished . . . to individuals of child-bearing age (including minors who can be considered to be sexually active) who are eligible under the State plan and who desire such services and supplies ....

42 U.S.C. $\$ 1396 \mathrm{~d}(\mathrm{a})(4)(\mathrm{C})(1982)$.

By expressly including such requirements in each of three programs, Congress sought to establish a federal policy that "prevents the vagaries of state law from disrupting the national scheme, and 
The legislative history of Title $\mathrm{X}$ reflects a congressional commitment to two paramount policies regarding contraceptive services for adolescents: (1) encouraging family involvement in a teenager's contraceptive decision; ${ }^{33}$ and (2) maintaining patient confidentiality regarding personal facts disclosed during the provision of services. ${ }^{34}$

In an effort to reiterate its commitment to family involvement, Congress amended Title $X$ in 1981 to include the following language: "[t]o the extent practical, entities which receive grants or contracts under [Title X] shall encourage family participation in projects assisted under this subsection." 35 The Conference Committee Report accompanying the amendment, however, clearly indicated the secondary nature of the family involvement goal:

The conferees believe that, while family involvement is not mandated, it is important that families participate in the activities authorized by this title as much as possible. It is the intent of the Conferees that grantees will encourage participants in Title X programs to include their families in counseling and involve them in decisions about services. ${ }^{36}$

guarantees a national uniformity that enhances the effectiveness of congressional policy." Planned Parenthood Ass'n v. Matheson, 582 F. Supp. 1001, 1004-05 (D. Utah 1983) (quoting Hisquierdo v. Hisquierdo, 439 U.S. 572, 584 (1979)). Thus, a federal district court recently invalidated a state notification statute identical to the DHHS "squeal rule" as (1) pre-empted by the legislative intent underlying Title X, and (2) unconstitutional under City of Akron v. Akron Center for Reproductive Health, 103 S. Ct. 2481 (1983) and H.L. v. Matheson, 450 U.S. 398 (1981). Planned Parenthood Ass'n v. Matheson, 582 F. Supp. at 1004-09.

33. See, e.g., S. REP. No. 29, 94th Cong., 1st Sess. 55 (1975) ("unmarried teenagers, where feasible, should be encouraged to involve their family in their decision about use of contraceptives"); 124 CoNG. REC. 16,448 (1978) (statement of Sen. Cranston) ("unemancipated minors requesting family planning services will be encouraged by projects, whenever feasible, to consult with the parents with respect to such services").

34. S. REP. No. 102, 95th Cong., 1st Sess. 26 (1977). DHHS regulations originally adopted in 1972 pursuant to Title $X$ still expressly protect this confidentiality:

All information as to personal facts and circumstances obtained by the project staff about individuals receiving services must be held confidential and must not be disclosed without the individual's consent, except as may be necessary to provide services to the patient or as required by law, with appropriate safeguards for confidentiality.

42 C.F.R. $\$ 59.11$ (1983) (originally codified at 42 C.F.R. $\$ 59.10$ (1972)).

35. 42 U.S.C. $\$ 300(a)$ (1982). The dispute over statutory construction between the Secretary of DHHS and opponents of the regulations revolves in large part around the words "shall encourage" and the breadth of authority conferred by such language. According to the Secretary, the word "shall" imposes a "nondiscretionary duty" on Title X grantees to communicate directly with the parents in order to involve them in the child's family planning decisions. See Brief for the Department of Health and Human Services at 18-19, Planned Parenthood Fed'n v. Heckler, 712 F.2d 650 (D.C. Cir. 1983) [hereinafter cited as Brief for DHHS].

36. H.R. CONF. REP. No. 208, 97th Cong., 1st Sess. 799 (1981), reprinted in U.S. CODE CONG. \& AD. NEws 596, 1161 (emphasis added) ("unemancipated minors requesting family planning services will be encouraged by projects, whenever feasible, to consult with the parents with respect to such services'). 
In addition to encouraging family involvement, Congress, with the interests of the adolescent clientele in mind, has insisted upon a policy of confidentiality in the Title $\mathrm{X}$ programs throughout the history of Title $X{ }^{37}$ In 1978 , Congress rejected an attempt to undermine this confidentiality, soundly defeating, by a vote of $45-10$ in the Senate, ${ }^{38}$ a proposed amendment to Title $\mathrm{X}^{39}$ that would have required parental notification of a clinic's intent to prescribe or dispense prescription contraceptives to minors under the age of sixteen. ${ }^{40}$

Although these dual congressional goals of family involvement and confidentiality are not inherently incompatible, the issue of the extent to which each goal properly may be pursued at the expense of the other remains. As a practical matter, striking a reasonable balance between the goals may be difficult because pursuit of one often depends on relinquishment of the other. There are essentially two options: clinics may cultivate parental involvement by direct communication with parents, over the adolescent's objection, thereby breaching patient confidentiality; or clinics may encourage the adolescent patient herself to involve her par-

37. Indeed, congressional efforts to induce teenagers to take advantage of the services offered by Title $\mathrm{X}$ clinics were sensitive to the adolescent's very real apprehension that her parents would discover that she was seeking contraceptives and was therefore sexually active. See S. REP. No. 822, 95th Cong., 2d Sess. 31 (1978) (quoting Willie Hamilton, President of the National Family Planning Forum and Executive Director of the Arkansas Family Planning Council: "the teenager may be rightfully concerned that her parents will learn or be told of her request for contraception"). A recent study by the Alan Guttmacher Institute of the reasons why adolescents prefer family planning clinics to private physicians reveals that over $30 \%$ of the adolescents fear that a private doctor might tell their parents of the request for contraceptives. Planned Parenthood Fed'n v. Schweiker, 559 F. Supp. 658, 666 n.14 (D.D.C.), aff'd sub nom. Planned Parenthood Fed'n v. Heckler, 712 F.2d 650 (D.C. Cir. 1983). As a result, the "well publicized and zealously guarded policy of confidentiality ensured by the clinics," $i d$. at 666 , has been a key factor in successfully attracting teenagers to family planning centers funded by Title $X$.

According to the most recent comprehensive study of birth control practices among American women, 55\% of all teenagers using a prescription contraceptive obtain these contraceptives through family planning clinics. ALAN GUTTMACHER INST., supra note 21, at 18. An earlier study of varying consent and notification policies among family planning facilities suggested that those facilities with minimal consent or notification policies experienced a significantly higher attendance rate by teenagers than those facilities with more intrusive requirements. Torres, Forest \& Eisman, Telling Parents: Clinic Policies and Adolescents' Use of Family Planning and Abortion Services, 12 FAM. Plan. Persp. 284, 287 (1980) (especially Table 4).

38. 124 CONG. REC. 37,044 (1978).

39. Id. (popularly known as the Volkmer amendment).

40. Text of amendment at 124 CoNG. REC. 37,044 (1978). The debate surrounding the Volkmer amendment is particularly instructive. See, e.g., 124 CONG. REC. 37,047 (1978) (statement of Rep. Preyer) ("If we are going to put some clout behind the intent of [Title X], we must think first and foremost about what can be done to prevent teenage pregnancies. . . [1]f these teenagers . . . have to seek parental consent for contraception, the whole intent of this legislation will be undermined."); id. (statement of Rep. Rogers); id. at 37,048 (statement of Rep. Weiss) ("I believe that passage of these amendments would ... result in an increase of unplanned and unwanted pregnancies."). 
ents, thereby preserving patient confidentiality. ${ }^{41}$ Faced with these options, the DHHS regulation resolved the conflict in favor of direct communication with parents.

\section{B. The DHHS Regulation.}

New York v. Schweiker 42 and Planned Parenthood Federation of America v. Schweiker 43 articulated the judiciary's disapproval of the DHHS regulation just two weeks after its promulgation. Although the regulation purported to "implement [the] 1981 amendment to Title X . . . to encourage, to the extent practical, family participation in the provision of [family planning] services," 44 both courts concluded that the mandatory notification requirement would undermine Title X's basic purpose: "stemming the increase in unwanted births and pregnancies" among teenagers. ${ }^{45}$

According to the courts, statistical evidence and logic indicated that such intrusive notification requirements would deter adolescents from using the Title $\mathrm{X}$ clinics. ${ }^{46}$ Moreover, most adolescents denied confidential access to Title $\mathrm{X}$ services would be unable to obtain adequate contracep-

41. Brief for NFPRHA, supra note 30 , at 6 .

42. 557 F. Supp. 354 (S.D.N.Y. 1983) (issuing a preliminary injunction). The district court subsequently issued a permanent injunction. New York v. Schweiker, Nos. 83 Civ. 0726, 0727 (S.D.N.Y. Mar. 14, 1983) (available Dec. 31, 1984 on LEXIS Genfed library, Dist file), aff'd sub nom. New York v. Heckler, 719 F.2d 1191 (2d Cir. 1983).

43. 559 F. Supp. 658 (D.D.C. 1983), aff'd sub nom. Planned Parenthood Ass'n v. Heckler, 712 F.2d 650 (D.C. Cir. 1983).

44. 48 Fed. Reg. 3600 (1983); see also supra text accompanying notes 35-36.

45. Planned Parenthood Fed'n v. Schweiker, 559 F. Supp. at 668; New York v. Schweiker, 557 F. Supp. at 359; Brief for Planned Parenthood at 9, Planned Parenthood Fed'n of Am. v. Heckler, 712 F.2d 650 (D.C. Cir. 1983) (citing S. Rep. No. 822, 95th Cong., 2d Sess. 27 (1978), H.R. Rep. No. 1191, 95th Cong., 2d Sess. 31 (1978)).

46. Planned Parenthood Fed'n v. Schweiker, 559 F. Supp. at 666; New York v. Schweikcr, 557 F. Supp. at 359. According to the most recent figures compiled by the DHHS, 615,000 persons aged 17 and younger utilized Title X clinics in 1981. Supporting Statement for Recordkeeping Requircments in Regulations Governing Family Planning Projects Funded Under Title X (cited in Addendum $\mathrm{F}$ to Brief for NFPRHA, supra note 30, at 58). Ninety-six per cent of this group consisted of unemancipated minors. Almost $80 \%$ of these teenagers chose prescription methods of contraceptives. Kenney, Forest \& Torres, Storm Over Washington: The Parental Notification Proposal, 14 FAM. Plan. Persp. 185 (1982). Adjusting its data to account for a minimal number of otherwise unemancipated unmarried adolescents who are nevertheless exempt from the regulations because they have previously given birth, the DHHS concluded that the total number of unemancipated adolescents who received prescription contraceptives from Title X clinics in 1981 and are thus potentially affected by the regulations is 418,900 . Supporting Statement of Recordkeeping Requirements in Regulations Governing Family Projects Funded Under Title X (cited in Addendum F to Brief for NFPRHA, supra note 30 , at 58).

When 1211 teenagers were surveyed concerning their likely reaction to such mandatory notification requirements, $23 \%$ responded that they would stop attending the clinics. Torres, Forest \& Eisman, supra note 37 at 290 . Indeed, the District Court for the District of Columbia in the Planned Parenthood case noted that "the mere proposal of the notification requirement . . . resulted in a 
tive care from alternative sources because of the prohibitively high cost of obtaining prescription contraceptives from a private physician, 47 and because nonprescription contraceptives which may be obtained relatively inexpensively from a drugstore are, as a practical matter, "significantly less effective than prescription contraceptives." 48

The courts concluded that the deterrent effects of the regulations pointed to one inevitable result-a significant increase in teenage pregnancies, ${ }^{49}$ precisely the problem Congress sought to remedy through Title $\mathrm{X}$. The conclusion rested upon studies suggesting that the number of adolescent pregnancies, abortions, and births would rise significantly if the regulation were to take effect, because of the expected changes in contraceptive use.50 One report indicated that "in one year, an addi-

significant drop in adolescent attendance at family planning clinics." Planned Parenthood Fed'n v. Schweiker, 559 F. Supp. at 666 n.13.

The district court opinion in Baird v. Bellotti, 393 F. Supp. 847 (D. Mass. 1975), considered the 16-year old plaintiffs reasons for not wanting her parents to know of her sexual activity and subsequent pregnancy:

Her father had told her, in connection with the pregnancy of a contemporary friend, that if that happened to her he would evict her and kill her boy friend. She did not know how far to believe this, except that she felt certain he would take some physical action against the

boy. ... Her reasons for not informing her parents were in part apprehension of what might happen to her as a result of their learning she had had intercourse, in part the fear of what would happen to her boy friend, and in part the desire to spare her parents' feelings.

Id. at 850 .

Unfortunately, while the "squeal rule" and its counterparts would certainly result in a significant decrease in contraceptive use by teenagers, it would not be likely to alter their sexual activity, even without protection. "The evidence. . . suggests that many minors will not quickly manifest the self-discipline counseled by the government, and will remain sexually active." Planned Parenthood Fed'n v. Schweiker, 559 F. Supp. at 666 . When 641,000 sexually active teenagers were asked what alternatives they would resort to if effective contraceptives became unavailable, 87,000 said that they would "switch to nonprescription methods, including withdrawal and rhythm, which have been shown to have relatively high failure rates," and another 26,000 said that they would continue to be sexually active without using any method. Torres, Forest \& Eisman, supra note 37, at 291.

47. The average first-year costs of prescription methods of contraceptions obtained through a private physician, including both the costs of supplies and medical care, are $\$ 172$ for the pill, $\$ 160$ for the diaphragm, and $\$ 130$ for the IUD. Excluding the possibility of subsequent office visits, the yearly costs after the first year taper off to approximately $\$ 107, \$ 66$, and $\$ 95$ respectively. ALAN GUTTMACHER INST., supra note 21, at 21. Adolescent patients receiving the same supplies and services from family planning clinics, by contrast, pay nothing if they qualify as low-income patients, or only a minimal fee if they do not. It is not surprising, therefore, that $60 \%$ of adolescents surveyed preferred the clinic "because a doctor is too expensive." Planned Parenthood Fed'n v. Schweiker, 559 F. Supp. at 666 n.14.

48. Planned Parenthood Fed'n v. Schweiker, 559 F. Supp. at 666; see ALAN GuTTMACHER INST., supra note 21 , at 5-9.

49. New York v. Schweiker, 557 F. Supp. at 359; Planned Parenthood Fed'n v. Schweiker, 559 F. Supp. at 666.

50. Planned Parenthood Fed'n v. Schweiker, 559 F. Supp. at 663 ("The studics and affidavits submitted by the plaintiffs convincingly demonstrate that the regulations will deter minors from attending family planning clinics and thereby increase their risk of becoming pregnant.") (citing Torres, Forest \& Eisman, supra note 37, at 290-91). Appellee-NFPRHA concluded that "the regu- 
tional 33,000 adolescents aged 17 or younger would become pregnant, resulting in 14,000 abortions, 9,000 out-of-wedlock births, and 4,000 miscarriages." 51

Although the "squeal rule" portion of the DHHS regulation received more publicity because of its explicit notification requirement, both courts also held that the regulation's economic eligibility requirements for contraceptive services under Title $\mathrm{X}$ imposed a de facto notification requirement that was equally suspect because "it has the same effect as the parental notification requirement." 52 The Planned Parenthood court observed that "[i]n order to determine whether she is qualified to receive services from the clinic, a minor would be required to obtain financial information from her parents," creating a "de facto parental notification requirement." 53 The court further observed that the redefinition of economic eligibility in effect imposed a consent requirement on minors who cannot qualify for subsidized services because their parents are too affluent. ${ }^{54}$ If the minor has no funds of her own, ${ }^{55}$ she would, in most instances, be forced to solicit financial assistance from her parents in order to pay for contraceptive services. "A parent could prevent her child from receiving contraceptive services simply by refusing to pay for them." 56

Given the legislative history of Title $\mathrm{X}$ and the likely consequences of the DHHS regulation, both New York v. Schweiker ${ }^{57}$ and Planned

lations would have the immediate and irreparable consequence of causing about 1000 unwanted births and about 1000 abortions each month." Brief of NFPRHA, supra note 30, at 8. "The long term adverse social and economic effects of births to women in this young age-group, especially of unintended and out-of-wedlock births and of early, forced marriages, have been well documented." Torres, Forest \& Eisman, supra note 37, at 291 (citing, inter alia, Baldwin \& Cain, The Children of Teenage Parents, 12 Fam. PLan. PerSP. 34 (1980); Fustenberg, The Social Consequences of Teenage Parenthood, 8 FAm. PLAN. PersP. 148 (1976); Moore \& Caldwell, The Effect of Government Policies on Out-of-Wedlock Sex and Pregnancy, 9 FAM. PLAN. PERSP. 164 (1977)).

51. Torres \& Eisman, The Impact of Restrictions on the Provision of Birth Control and Abortion Services on Teenage Fertility, (paper presented at the annual mecting of the American Public Health Association, Detroit, October 19-23, 1980, cited in Torres, Forest \& Eisman, supra note 37, at 291).

52. Planned Parenthood Fed'n v. Schweiker, 559 F. Supp. at 669; see aiso New York v. Schweiker, 557 F. Supp. at 362.

53. Planned Parenthood Fed'n v. Schweiker, 559 F. Supp. at 669.

54. Id.

55. Many teenagers cannot easily afford the cost of contraceptive services obtained through private sources. See supra note 47.

56. Planned Parenthood Fed'n v. Schweiker, 559 F. Supp. at 669.

57. Nos. 83 Civ. 0726, 0727 (S.D.N.Y. Mar. 14, 1983) (unpublished order granting permanent injunction) (available Dec. 31, 1984 on LEXIS, Genfed library, Dist file), aff'd sub nom. New York v. Heckler, 719 F.2d 1191 (2d Cir. 1983). The court's earlier order of a preliminary injunction is available as a published opinion. New York v. Schweiker, 557 F. Supp. at 362 (Plaintiffs "have established a very strong probability of succeeding on their claim that the regulations are contrary to the intent of Congress and would defeat the basic purpose of Title X.") 
Parenthood v. Schweiker ${ }^{58}$ permanently enjoined the enforcement of the regulation as promulgated in contravention of its authorizing statute and thus, in excess of the DHHS' delegated authority. Adopting the lower courts' reasoning, appellate courts affirmed their decisions. ${ }^{59}$

Because the only courts to consider the DHHS regulation thus far have invalidated it on statutory grounds, no court ${ }^{60}$ has addressed the constitutional issues raised by the federal regulation. ${ }^{61}$ The trial and appellate courts in both New York v. Schweiker and Planned Parenthood v. Schweiker expressly reserved the question of the constitutionality of the

58. 559 F. Supp. at 669 . (defendants "permanently enjoined from implementing or enforcing regulations amending 42 C.F.R. Part 59").

59. New York v. Heckler, 719 F.2d 1191 (2d Cir. 1983), aff'g New York v. Schweiker, Nos. 83 Civ. 0726, 0727 (S.D.N.Y. Mar. 14, 1983) (available Dec. 31, 1984 on LEXIS, Genfed library, Dist file); Planned Parenthood Fed'n v. Heckler, 712 F.2d 650 (D.C. Cir. 1983), aff'g Planned Parenthood Fed'n v. Schweiker, 559 F. Supp. 658 (D.D.C. 1983). Although split panels decided both the District of Columbia and the Second Circuit cases, the majority opinions in each denounced the validity of the regulations after an exhaustive statutory analysis. Finding the Conference Committee Report to be "a crystal clear and unequivocal expression of congressional intent," the District of Columbia Circuit concluded that the rulemaking authority of the DHHS does not extend to permitting Title $\mathrm{X}$ grantees to communicate directly with the parents as a means of fulfilling the statute's "family participation" directive. 712 F.2d at 657 . Title X clinics may permissibly be required to encourage their adolescent patients to involve their parents in a dialogue, but the clinics may not initiate this dialogue with the parents over the child's objection because "Congress most definitely did not intend to mandate family involvement." Id. (emphasis in original). Judge Skelly Wright, writing for the District of Columbia panel, diplomatically noted that the decision did not pass on the moral and political wisdom of the regulations, but only on their legality. Id. at 665 .

The dissenters in each case did not challenge the majorities' interpretations of the relevant legislative history, nor did they refute the appellees' statistical findings concerning the likelihood of increased teenage pregnancies. Judge Bork in the District of Columbia Circuit dissented only to the extent that DHHS should have had an opportunity to correct its initial errors and lawfully reissue the regulations under proper authority before the courts conclusively determined their validity. Id. at 667. Judge Friendly dissented in part in the Second Circuit case on the ground that the entire proceedings were merely duplicative of the District of Columbia proceedings which already had been resolved on appeal three months earlier. 719 F.2d at 1197-98. Because an effective injunction already had issued, which the Second Circuit could not affect, its holding was merely an "advisory opinion" in Friendly's view. Id. at 1198.

60. Although many expected the Justice Department to seek Supreme Court review of both the District of Columbia and the Second Circuit decisions, the Reagan administration made a last-minute decision not to seek review in the High Court because there was no conflict among the circuits. Wash. Post, Dec. 1, 1983, at A21, col. 1.

61. Cf. Harris v. McRae, 448 U.S. 297, 306-07 (1980) ("It is well settled that if a case may be decided on either statutory or constitutional grounds, [a court], for sound jurisprudential reasons, will inquire first into the statutory question."). Nevertheless, a federal district court in Utah recently considered the constitutionality of a state statute similar to the DHHS regulation. Although the court held the statute invalid as preempted by Title $\mathrm{X}$, it also went on to hold it unconstitutional as an infringement of privacy interests, particularly a minor's "constitutionally protected right to decide whether to bear or beget a child by using contraceptives." Planned Parenthood Ass'n v. Matheson, 582 F. Supp. 1001,1009 (D. Utah 1983). 
regulation, ${ }^{62}$ noting the privacy rights implicated. The constitutional questions, however, are far from moot because a reauthorized "squeal rule" that could withstand statutory challenge would be subject to constitutional review. Because Congress has never expressly prohibited the Secretary of DHHS from adopting a parental notification rule, DHHS might promulgate a modified squeal rule without legislative action, under the authority of an existing statute other than Title X.63 Alternatively, the possibility exists that Congress may enact "squeal rule" legislation.

Because these possibilities remain, this note will consider the constitutional implications of the "squeal rule." Even though the separate issues of parental notification and consent, minors' privacy rights, and governmental benefits liave received extensive judicial and legislative treatment, the questions raised by the "squeal rule" remain unresolved. Because the "squeal rule" involves all of these issues, it offers a unique

62. See New York v. Heckler, 719 F.2d at 1194 n.3; Planned Parenthood Fed'n v. Heckler, 712 F.2d at 654 n.21; Planned Parenthood Fed'n v. Schweiker, 559 F. Supp. 669 n.19; New York v. Schweiker, 557 F. Supp. at 362.

63. See Planned Parenthood Fed'n v. Heckler, 712 F.2d at 667 (Bork, J., dissenting). Arguing that the DHHS should be given an opportunity to decide whether to readopt the regulations under some statutory authority other than the 1981 amendments, the dissent in the District of Columbia appeal points out that the

Secretary . . . has a rulemaking power that would authorize the notification regulation challenged here unless Congress has deprived the Secretary of that particular authority. Certainly Congress has not done so by any statutory language, and . . . only a few snippets of . . . legislative history . . . can offer any support at all for an inference of congressional restriction of otherwise broad agency authority.

Id. (Bork, J., dissenting). On appeal, the DHHS urged that Title XX, the Adolescent Family Life Demonstration Projects Act, provided alternative authorization for the "squeal rule" because that statute expressly requires family involvement by mandating parental notification and consent, in addition to determining eligibility for the program on the basis of family income. See 42 U.S.C. $\S \S$ $300-5(a)(22)(A)(i),-3(c)(1982)$. Arguing that Congress' philosophical intent in Title XX logically informs any interpretation of Title $\mathrm{X}$ because Title $\mathrm{XX}$ was enacted as part of the same legislative packet as the 1981 amendment to Title X, DHHS contended that congressional approval of parental notification in one context implies such approval in a related context. See Brief for DHHS, supra note 35 , at 22-24. The court rejected this argument by distinguishing the "very different nature of the two programs" created by the two statutes. See Planned Parenthood Fed'n v. Heckler, 712 F.2d at 661-63. The court stated:

Title $\mathrm{X}$ is the largest of the Federal Government's family planning programs, designed to serve the family planning needs of all persons in need of such services. Title $\mathrm{XX}$, by contrast, is a limited and experimental program; it provides for "demonstration projects" with a special emphasis on serving the needs of already pregnant adolescents and the prevention of adolescent sexual relations. . . . While some traditional family planning services may be provided under limited circumstances, . . . the primary thrust of Title XX clearly lies elsewhere.

The distinct differences in the scope and purposes of the two programs necessarily dictate different approaches to striking an appropriate balance between the need for confidentiality and the goal of parental involvement.

Id. at 661-62.

Suggestions of more viable sources of alternative legislative authority are beyond the scope of this note. 
invitation to consider the constitutional questions that arise where they overlap and interact.

\section{CONSTITUTIONAL IMPLiCATIONS}

The law of substantive due process prescribes a standard method of analysis to determine the constitutionality of governmental regulation that burdens a fundamental right. ${ }^{64}$ In order to justify such legislation and withstand constitutional scrutiny, the government must demonstrate that a sufficient governmental interest ${ }^{65}$ is served by the regulation. The

64. The right of privacy cases generally have involved challenges to state laws brought under the due process clause of the fourteenth amendment and are thus part of the case law of substantive due process. Although the fourteenth amendment does not apply to the federal government, the same right to privacy limitations do. See infra note 65. Even if it is technically incorrect to speak of a "substantive due process" right to privacy in relation to the federal government, it is frequently done. See, e.g., Miller v. Rumsfield, 647 F.2d 80, 85-86 (Norris, J., dissenting from denial of rehearing en banc). This merely points out the similarity of the interests and analysis involved, whether in relation to state or federal regulations. See infra note 65 .

65. The boundaries of the right of privacy generally have been drawn in cases dealing with state regulations. E.g., Roe v. Wade, 410 U.S. 113 (1973); Griswold v. Connecticut, 381 U.S. 479 (1965). Thus, where the right of privacy is burdened, the state's interests in furthering the goals served by the challenged regulation must be weighed in order to determine whether its imposition is constitutionally permissible. Wade, 410 U.S. at 162-64. This limitation, however, is not restricted to state legislation. Rather, because the right of privacy finds its basis in the Bill of Rights, see infra note 68, it limits the power of government in general, not just that of the states. Thus, no lesser showing of governmental interest should be sufficient to uphold a federal regulation than is required to uphold a state regulation. Cf. United States v. O'Brien, 391 U.S. 367, 376-77, $381-82$ (1968) (applying to federal government standards of review developed in first amendment challenges to state government regulations). If anything, a greater showing should be required. After all, the Bill of Rights was framed to apply against the federal government directly; its protection against state legislation is realized only indirectly through the due process clause of the fourteenth amendment. See generally L. TRIBE, AMERICAN CONSTITUTIONAL LAW § 11-2 (1978).

One may argue that state power is distinguishable from federal power in that the Constitution does not confer upon Congress the general police power which the states traditionally exercise to protect the "public health, safety, morals, or general welfare." Washington ex rel. Seattle Title Trust Co. v. Roberge, 278 U.S. 116, 120-21 (1928). However, as Congress may act to promote health and morality through its taxing and spending or other federal powers, federal interests in such goals arguably should be accorded a weight similar to the corresponding state interests. $C f$. Hamilton v. Kentucky Distilleries \& Warehouse Co., 251 U.S. 146, 155-56 (1919) (no valid objection that exercise of federal power may be attended by the same incidents which attend exercise by a state of its police power or that it may tend to accomplish a similar purpose).

General constitutional principles aside, with respect to a program such as Title $X$, state and federal government action and interests are inextricably intertwined. Because the DHHS "squeal rule" was to be applied by arms of the state governments that participate in Title $\mathrm{X}$ programs, see supro note 27 and accompanying text, its underlying rationale might be treated in part as a traditional expression of state interests. Thus, this note will assume that the same interests that would be required to uphold a state regulation might also be sufficient to justify a federal "squeal rule."

Because the regulation at issue was promulgated by the federal government, it is the federal government in this instance that has the burden of proving a sufficient federal governmental interest. Because the interests of the federal government mirror the interests of state and local governments with respect to the rights at issue, and because the "squeal rule" requires state governments to 
strength of any such governmental interest depends upon the nature of the right restricted. As a general rule, legislation that infringes fundamental rights must be justified by the showing of a "compelling state interest." 66 Similarly, the strength of the relationship required to be proved between the regulation and the futherance of the state's interest depends upon the constitutional strength of the right. Thus, where a fundamental right is involved, the state has the burden of proving that the regulation is necessary to achieve its "compelling interest." 67

\section{A. The Right of Privacy.}

It is well-settled that the Constitution protects a fundamental right of privacy, which encompasses certain zones of personal privacy. ${ }^{68}$ Individual freedom to make personal decisions regarding contraception is firmly established as part of this right of privacy. ${ }^{69}$ In Griswold v. Connecticut, the Supreme Court invalidated a state statute which criminal-

participate in its enforcement, the terms "governmental interests" and "state interests" will be used interchangeably throughout this note.

66. Roe v. Wade, 410 U.S. 113,155 (1973).

67. See Griswold v. Connecticut, 381 U.S. 479, 485 (1965) (a legitimate purpose may not be achieved by regulations that "sweep unnecessarily broadly and thereby invade the area of protected freedoms" ") (quoting NAACP v. Alabama, 377 U.S. 288, 307 (1964); cf. Shapiro v. Thompson, 394 U.S. 618, 634 (1969) ("any classification which serves to penalize the exercise of [the constitutional right to travel], unless shown to be necessary to promote a compelling governmental interest, is unconstitutional') (emphasis in original), cited in Wade, 410 U.S. at 155. But cf. infra notes 111-15 and accompanying text (somewhat less rigorous standards may apply to limitations on ininor's rights).

68. Although not explicitly mentioned in the Constitution, the right of privacy has been derived from a number of constitutional sources, including the first amendment, see Stanley v. Georgia, 394 U.S. 557, 564 (1969), the due process clause of the fifth and fourteenth amendments, $c f$. Meyer v. Nebraska, 262 U.S. 390, 399 (1923) (recognizing right "to marry, establish a home and bring up children"), the ninth amendment, see Griswold v. Connecticut, 381 U.S. 479, 486.87 (1965) (Goldberg, J., concurring), and the penumbras of the Bill of Rights, see id. at 484-85.

Although this guarantee of constitutional protection extends only to those rights deemed "fundamental" or "implicit in the concept of ordered liberty," Roe v. Wade, 410 U.S. 113, 152 (1973) (quoting Palko v. Connecticut, 302 U.S. 319, 325 (1937)), the Supreme Court historically has construed the right of privacy broadly enough to encompass personal choices that are integral to the individual's bodily integrity and sense of self, even when these choices do not necessarily reflect majoritarian values.

The Court has recognized a fundamental right of privacy in the areas of marriage, see Loving v. Virginia, 388 U.S. 1, 12 (1967); procreation, see Skinner v. Oklahoma, 316 U.S. 535, 541 (1942); family relationships, $c f$. Prince v. Massachusetts, 321 U.S. 158, 166 (1944) (recognizing "the private realm of family life which the state cannot enter") (dicta); child rearing and education, $c f$. Pierce $v$. Society of Sisters, 268 U.S. 510, 535 (1925) (under the "fundamental theory of liberty upon which all governments in this Union repose" parents have right to educate their children in parochial schools); cf. Meyer v. Nebraska, 262 U.S. 390, 399 (1923) (due process right "to marry, establish a home and bring up children"); contraception, see Eisenstadt v. Baird, 405 U.S. 438, 453 (1972); and abortion, see Roe v. Wade, 410 U.S. 113, 153 (1973).

69. See Carey v. Population Servs. Int'l, 431 U.S. 678, 685 (1977); Eisenstadt v. Baird, 405 U.S. 438, 453 (1972); Griswold v. Connecticut, 381 U.S. 479, 485 (1965). 
ized the use of contraceptives on the ground that it violated a fundamental right of privacy inherent in the marital relationship. ${ }^{70}$ Seven years later, in Eisenstadt v. Baird, the Court held that the right to use contraceptives applied equally to unmarried persons because no rational justification existed for the statutory distinction between married and unmarried persons. ${ }^{71}$ In Carey v. Population Services International, the Court declared unconstitutional a state statute prohibiting the distribution of contraceptives to minors under the age of sixteen, holding that the "decision whether or not to beget or bear a child is at the very heart of [the] cluster of constitutionally protected choices" contemplated by the right of privacy. ${ }^{72}$ Griswold and Eisenstadt, therefore, established the right to use contraceptives free from unwarranted governmental intervention, while Carey established an essentially derivative right of access to contraceptives. ${ }^{73}$

The right to reproductive freedom implicit in the right of privacy arguably encompasses the right to engage in nonmarital sexual activity as well. The irony that pervades the Supreme Court's line of cases recognizing the individual right to make contraceptive decisions, ${ }^{74}$ however, is its steadfast reluctance to acknowledge the right to engage in the sexual activity that gives rise to these decisions in the first place. ${ }^{75}$ The only clear guidelines the Court has offered to determine whether certain sex-

70. 381 U.S. 479, 499 (1965) (Goldberg, J., concurring).

71. 405 U.S. 438,453 (1972).

72. 431 U.S. 678,685 (1977).

73. Id. at 687-89. The right of access to contraceptives is not fundamental in and of itself, but rather derives from the right to use them, because "access is essential to exercise of the constitutionally protected right of decision in matters of childbearing." Id. at 688.

74. Decisions whether to bear or beget a child encompass the decision to abort the pregnancy. Roe v. Wade, 410 U.S. 113, 152-53 (1973).

75. One commentator cryptically suggests that "[c]ontraception and sexual relations are simply two different things, one of which can be given legal protection without protecting the other." Hafen, The Constitutional Status of Marriage, Kinship, and Sexual Privacy-Balancing the Individual and Social Interests, $81 \mathrm{MiCH}$. L. REV. 463, 531 (1983). However, the decision to engage in sexual activity logically precedes-and is therefore implied in-the decision to use a contraceptive.

In a footnote, the plurality opinion in Carey sidestepped the question that the parties had urged upon the Court: "We observe that the Court has not definitively answered the difficult question whether and to what extent the Constitution prohibits state statutes regulating [private consensual sexual behavior] among adults." Carey, 431 U.S. at 694 n.17 (plurality opinion). In separate concurring and dissenting opinions, however, Justices Powell and Rehnquist expressed a more definitive position on this subject. Cautioning that sexual freedom should not be defined too broadly to give "extraordinary" constitutional protection, Justice Powell argued that "there is . . . no justification for subjecting restrictions on the sexual activity of the young to heightened judicial review." Id. at 705 (Powell, J., concurring). According to Justice Rehnquist, the Court's summary affirmance of Doe v. Commonwealth Attorney, 425 U.S. 901 (1976), mem. aff'g 403 F. Supp. 1199 (E.D. Va. 1975) (upholding the constitutionality of a statutory prohibition of sodomy between consenting adults), definitively established the "facial constitutional validity" of state restrictions on consensual activity. Carey, 431 U.S. at 718 n.2 (Rehnquist, J., dissenting). 
ual activity is constitutionally protected have been given in the context of the marital relationship, ${ }^{76}$ or involved procreative capacities that may give rise to a mother-child relationship. ${ }^{77}$ Nevertheless, that the Court has recognized a fundamental right to use contraceptives implies that there is no procreative prerequisite for constitutional protection of ordinary heterosexual intercourse.

If there is a constitutionally protected right to make certain personal decisions regarding one's sexual activity, it is necessary to determine whether this right applies with equal force to minors. The Supreme Court consistently has recognized that "a child, merely on account of his minority, is not beyond the protection of the Constitution."78 More specifically, the Court expressly has held that "the right to privacy in connection with decisions affecting procreation extends to minors as well as to adults." 79

While recognizing a minor's general right to constitutional protection, the Court nevertheless has concluded in a variety of contexts that "the constitutional rights of children cannot be equated with those of adults." 80 Broader restrictions on the rights of minors frequently are justified as a means of protecting a minor against her own immaturity and

76. Griswold v. Connecticut, 381 U.S. 479, 485-86 (1965).

77. See, e.g., Skinner v. Oklahoma, 316 U.S. 535, 541-42 (1942). Hafen argues that the cases dealing with contraceptive rights, including abortion, for unmarried persons restrict the term "right of privacy" to those decisions regarding childbearing. Hafen, supra note 75, at 519-20. Indeed, Eisenstadt and Carey speak of the fundamental nature of the contraceptive right only in relation to the "decision whether to bear or beget a child," Eisenstadt, 405 U.S. at 453; Carey, 431 U.S. at 685, and do not address the privacy interest inherent in the circumstances leading to the decision.

78. Bellotti v. Baird, 443 U.S. 622, 633 (1979); see also Planned Parenthood v. Danforth, 428 U.S. 52, 74 (1976) ("Minors, as well as adults, are protected by the Constitution and possess constitutional rights"); In re Gault, 387 U.S. 1, 13 (1967) ("neither the Fourteenth Amendment nor the Bill of Rights is for adults alone"). For a survey of the Supreme Court's "ad hoc adjudication" of the various constitutional rights extended to minors, see generally Note, The Minor's Right of Privacy: Limitations on State Action after Danforth and Carey, 77 CoLUM. L. REv. 1216, 1220 n.28 (1977).

79. Carey, 431 U.S. at 693.

80. Bellotti, 443 U.S. at 634. Acknowledging in Carey its historical commitment to protecting minors, the Court conceded that "in the area of sexual mores, as in other areas, the scope of permissible state regulation is broader as to minors than as to adults." Carey, 431 U.S. at 694. Without elaborating further, the Court notes only that "the Constitution does not bar state regulation of the sexual behavior of minors." Id. Although "the power of the state to control the conduct of children reaches beyond the scope of its authority over adults," Prince v. Massachusetts, 321 U.S. 158, 170 (1944), the question of "the extent of state power to regulate conduct of minors not constitutionally regulable when committed by adults is a vexing one, perhaps not susceptible of precise answer." Carey, 431 U.S. at 692.

In Michael M. v. Sonoma County Super. Ct., 450 U.S. 464 (1981), the Court upheld the conviction of a minor male for violating a statutory rape law prohibiting sexual intercourse with a female under 18 years of age. The Court upheld the statute against an equal protection challenge to its gender discrimination; only males could be convicted under the law. The defendant did not challenge the statute's regulation of sexual conduct on privacy grounds, and the Court did not address the constitutional issues that such a challenge would have raised. 
imprudence. ${ }^{81}$ The state's interest in protecting its young people from harm, however, does not affect the fundamental nature of the minor's right, but rather, is a separate factor to be weighed in order to evaluate whether the right is burdened justifiably. In itself, the state interest does nothing to diminish the fundamental nature of the minor's constitutional right. ${ }^{82}$ Accordingly, this note will consider the implications of the fact that minors are involved, in light of the relevant governmental interests. ${ }^{83}$

By burdening a minor's decision to seek contraception free from unjustified governmental interference, the mandatory parental notification requirement imposed by the "squeal rule" may infringe the minor's right of privacy. It abridges both the right to obtain and use contraceptives, and the implicit right to engage in non-marital sexual activity. ${ }^{84}$

\section{B. Burdening the Right of Privacy.}

By imposing a mandatory parental notification/consent requirement on a minor's decision to obtain contraceptives from Title $\mathrm{X}$ clinics, the

81. Cf. Hafen, supra note 75 , at 513 ("To be protected against [the] risk [of] . . childish choices . . . requires a restriction on the range of choice requirements."); see also H.L. v. Matheson, 450 U.S. 398, 422 (1981) ("The State's interest in protecting a young person from harm justifies the imposition of restraints on his or her freedom even though comparable restraints on adults would be constitutionally impermissible.") (quoting Planned Parenthood v. Danforth, 428 U.S. 52, 102-03 (1976)).

82. One commentator has erroneously blurred the distinction between rights and state interests, by arguing that a curious tension exists between the state interest and the right whenever a fundamental right is involved:

While the fundamental nature of constitutional rights argues for their free extension to minors without imposition of a capacity requirement, the exercise of these rights often involves activities posing risks which minors have normally been considered to be incapable of understanding. Thus, minors have been accorded significant constitutional protection where exercise of the right involves few risks but have generally been denied constitutional rights . . . where the activity involved has traditionally been viewed as posing serious consequences for the minor.

Note, supra note 78, at 1221-22. This tension is acutely present in the area of contraceptive rights for minors since the decisions to use contraceptives or to undergo an abortion often carry serious long-term risks to the physical and psychological health of a teenage girl which may not be immediately obvious to her. The risks associated with the use of contraceptives are significantly fewer than those associated with abortion which is, by contrast, a major medical procedure. See infra notes 166-69. Because the alternative to contraception and abortion, however, often is to carry a pregnancy to term, see infra text accompanying note 170 , a rcalistic approach would require this balancing test to factor in the risks associated with teenage pregnancy.

83. See infra text accompanying notes 116-161.

84. The DHHS regulation also infringes the right to confidentiality regarding personal information. Because the right to confidentiality is itself a very broad area with only tangential associations to sexual privacy, an in-depth discussion of this aspect of the minor's privacy is beyond the scope of this note. See generally Note, The Constitutional Right to Confidentiality, 51 GEO. WASH. L. REV. 133 (1982); Tettenborn, Breach of Confidence, Publicity and the Public Interest, 98 LAW Q. REV. 5 (1982); Comment, Administrative Investigation-Resisting Government Acquisition of Confidential Information, 28 U. KAN. L. REV. 447 (1980). 
"squeal rule" unduly burdens the minor's right to alone make such personal decisions. By thus requiring the minor to forfeit her constitutional right to make those decisions individually without parental involvement as a condition of receiving the federally funded benefits of Title $X$, the DHHS regulation impermissibly burdens the right of privacy by attaching unconstitutional conditions on its exercise.

The DHHS defends its current regulations in part on the ground that there is no interference with the minor's personal decision. According to the DHHS, there is no interference because: (1) the minor is not required to include her parents in the decisionmaking process; ${ }^{85}$ (2) the notification requirement does not give parents the kind of veto power implicit in a consent requirement; ${ }^{86}$ and (3) there are alternative nonTitle $\mathrm{X}$ means of obtaining contraceptives. ${ }^{87}$

1. Parental Involvement in the Decisionmaking Process. The first argument of DHHS is that there is no interference with the minor's personal decision because notification is required only after contraceptives have been obtained; ${ }^{88}$ the minor is not required, therefore, to include her parents in the actual decisionmaking process. ${ }^{89}$ DHHS further argues that the "parental notification regulation does not prevent any parent or guardian who receives a notice from refusing to become involved in any way in decisions about a child's sexual activities. . . . It merely provides the opportunity for participation if the parent elects to become involved."9o

These arguments are defective. First, the timing distinction attempted by DHHS ignores the reality that the mere threat of unwelcome parental involvement in the minor's contraceptive decision is likely to have a significant deterrent effect on a minor's use of Title $X$ clinics. ${ }^{91}$

85. Brief for DHHS, supra note 35 , at 25-26.

86. Id. at 26 .

87. Id. at 13,45 .

88. The regulation provides in part that: "a project shall, [w]hen prescription drugs or prescription devices are initially provided by the project to an unemancipated minor, notify a parent or guardian that they were provided, within 10 working days following their provision." 42 C.F.R. $\S 59.5(\mathrm{a})(12)(\mathrm{i})(\mathrm{A})$ (1983) (emphasis added).

89. DHHS contends that the notification requirement does not necessarily ensure parental involvement, but rather "provides [only] the opportunity for participation if the parent elects to become involved." Brief for DHHS, supra note 35, at 26 (emphasis added). Even if one concedes this distinction in the actual decisionmaking process, it acknowledges only a short-lived right of privacy. Contraceptive care commonly requires a continuing relationship with the physician in order to obtain prescription refills or to ensure that the diaphragm or IUD does not need refitting or replacing. Thus, even if a teenage girl physically can obtain some method of contraception, not subject to her parent's approval during her first visit to the clinic, her parents' subsequent disapproval after being notified may inhibit a second visit.

90. Brief for DHHS, supra note 35 , at 25-26 (emphasis added).

91. See supra note 46 and accompanying text. 
Second, by conditioning active parental involvement on the parent's choice to initiate discussion with his or her minor child, 92 rather than on the teenager's preference, the regulation effectively undermines the minor's ability to remain independent in the process.

2. Notification as Consent. DHHS further $\operatorname{argues}^{93}$ that the regulations are not impermissibly intrusive because they do not give anyone, including parents, the kind of veto power over the minor's decision that the Supreme Court struck down in both Planned Parenthood v. Danforth ${ }^{94}$ and Bellotti v. Baird. ${ }^{95}$ In Danforth, the Court invalidated portions of a Missouri statute that required a female seeking an abortion to obtain spousal consent if married, or parental consent if unmarried and under the age of eighteen. ${ }^{96}$ Relying on Danforth, the Court held in Bellotti v. Baird that if a state requires a pregnant minor to obtain parental consent for an abortion, it must also provide an alternative means of securing authorization for the abortion in the absence of parental consent, in order to ensure that the parent does not exercise an "absolute, and possibly arbitrary, veto that was found impermissible in Danforth."97

It is true that notification requirements generally are considered to be less intrusive than consent requirements, ${ }^{98}$ but notification requirements may nevertheless place unconstitutional burdens on fundamental rights. The obstacles notification creates, moreover, are particularly long-lived in the area of contraception which, unlike abortion, is not a

\footnotetext{
92. See supra note 90 and accompanying text.

93. Brief for DHHS, supra note 35 , at 47.

94. 428 U.S. 52 (1976).

95. 443 U.S. 622 (1979).
}

96. 428 U.S. at 69,74 . By involving a third party, usually a spouse or a parent, in a female's decision to use contraceptives or obtain an abortion, consent provisions generally encourage the third party to contribute to the outcome of the decision. Because the view of only one party can prevail in the event of a disagreement, the effect of a consent requirement is to give a veto power to a third party whose interest is merely derivative of the woman's more direct interest. See id. at 71 ("Inasmuch as it is the woman who physically bears the child and who is the more directly and immediately affected by the pregnancy, . . the balance weighs in her favor.").

97. 443 U.S. at 644.

98. See, e.g., H.L. v. Matheson, 450 U.S. 398, 411 n.17 (1981) (Court declined to equate notice and consent requirements); Bellotti v. Baird, 443 U.S. 622,640 (1979) (Court declined to equate notice and consent requirements). This argument carries little weight, however, if one accepts the proposition that "it is the presence of the notice requirement, and not merely its implementation in a particular case, that signifies the intrusion." H.L. v. Matheson, 450 U.S. at 440 n.27 (Marshall, J., dissenting) (emphasis added); see Planned Parenthood Fed'n v. Schweiker, 559 F. Supp. 658, 666 n.13 (D.D.C. 1983) ("the mere proposal of the notification requirement resulted in a significant drop in adolescent attendance at family planning clinics") (emphasis in original); see also Note, supra note 78, at 1240 (Because the prospect of parental involvement may be sufficient to discourage inany minors from obtaining contraceptives or safe, legal abortions, notice requirements burden the uninor's choice in much the same manner as parental consent requirements.). 
one-time incident subject to a one-time veto. ${ }^{99}$ On the contrary, because contraception implies a continuing pattern of activity which may be subject to parental restriction beyond the initial visit to the clinic, ${ }^{100}$ notification in the context of contraception more closely resembles the kind of deference to parental approval that consent provisions mandate. Even if a parent cannot veto a minor child's decision to obtain contraceptives the first time, because notification would not be given until after contraceptives had already been provided, parental disapproval after that notification could inhibit the minor from returning to the clinic for a second visit to obtain additional contraceptives, or from using the contraceptives she has already obtained. Because the regulation alerts parents not simply to the occurrence of an isolated event, but also affords them an intimate knowledge of their child's ongoing conduct, it may significantly affect the parent-child relationship in a variety of contexts. Through such influences it may affect indirectly the minor's decision to obtain or use contraceptives. ${ }^{101}$

In addition to imposing this intrusive notification requirement on the low-income minors who qualify for Title $X$ services, the DHHS regulation also may infringe the privacy rights of minors who do not qualify for such services. The DHHS regulation arguably operates as a de facto consent requirement $t^{102}$ by denying federally subsidized contraceptive services to minors of moderate- and high-income families who must in turn rely on their parents to subsidize the considerably higher cost of private contraceptive care.

3. Unconstitutional Conditions. The "squeal rule" further infringes the minor's right of privacy by placing unconstitutional condi-

99. Arguably, a decision concerning contraception is not directly analogous to the abortion decision in that the latter is compounded by inherent time limitations necessitating a speedy resolution. In this view, the minor's decision to use contraceptives has been more closely likened to the minor's decision to marry and the attendant restrictions thereto. See, e.g., Planned Parenthood Ass'n v. Matheson, 582 F. Supp. 1001, 1008 \& n.7 (D. Utah 1983) (citing Moe v. Dinkins, 533 F. Supp. 623 (S.D.N.Y. 1981) (upholding New York law prohibiting the marriage of minors between the ages of 14 and 18 absent the consent of both parents)). The contraceptive deeision bears more similarity to the abortion decision than to the decision to marry, however, in that "it cannot be delayed until the minor reaches the age of majority without posing the risk of serious harm to the minor." Matheson, 582 F. Supp. at 1008-09. As the Dinkins court noted, "[gliving birth to an unwanted child involves an irretrievable change in position for a minor as well as for an adult, whereas the temporary denial of the right to marry does not." 533 F. Supp. at 630.

100. See supra note 89.

101. Justice Marshall has observed that the consequences of revealing such a confidential decision may lead to "parental disappointment and disapproval, . . . physical or emotional abuse, withdrawal of financial support, or actual obstruction of the abortion decision." H.L. v. Matheson, 450 U.S. at 438-39 (Marshall, J., dissenting). Similar consequences may follow from notification regarding contraceptive use. See supra note 46.

102. See supra text accompanying notes 54-56. 
tions on her exercise of that right. DHHS maintains that the right of access to contraceptives is unimpaired because Title $X$ services remain readily available to those who are willing to tolerate the attached condition of parental notification, ${ }^{103}$ and because non-Title $X$ contraceptive options exist for those who would forego parental notification. ${ }^{104}$

It is well-established that the decision whether to subsidize constitutionally protected activity "is a question for Congress to answer, not a matter of constitutional entitlement."10s Once the legislature chooses to fund such activity, however, "the manner in which it dispenses benefits is subject to constitutional limitations." 106 More specifically, the power of the state to attach conditions to the grant of a privilege is limited in one crucial respect: "it may not impose conditions which require the relinquishment of constitutional rights." 107 In implementing Title X, Congress has chosen to subsidize the constitutionally protected activity of obtaining contraceptive care. Having done so, it must ensure that the subsidy is distributed in a constitutionally permissible way. By attaching certain "conditions" to eligibility for federally funded benefits, however, the DHHS regulation in effect exerts a coercive pressure on the teenager to choose between receiving contraceptives on the government's terms or exercising her constitutional right to make a private decision-at the expense of those benefits. ${ }^{108}$ As such, the regulation seems to fall within that category of restrictions prohibited by the Supreme Court as penalizing the exercise of a constitutional right. ${ }^{109}$

In light of these unconstitutional conditions, the DHHS' insistence on the viability of alternatives to Title $\mathrm{X}$ services is of little consequence. The existence of such options fails to remedy the constitutional deficiencies of the "squeal rule" itself. Moreover, the perceived emergency

103. Reply Brief for DHHS at 33, Planned Parenthood Fed'n v. Heckler, 712 F.2d 650 (D.C. Cir. 1983) [hereinafter cited as Reply Brief for DHHS].

104. Brief for DHHS, supra note 35 , at 45 . DHHS urges that lenient parental notification practices among private physicians dispensing contraceptives to minors make it "easy" to obtain prescription contraceptives from non-Title X sources without notification. Reply Brief for DHHS, supra note 103, at $31 \mathrm{n} .18$. This assertion is based on a nationwide survey of pediatricians that indicated that $79 \%$ would provide contraceptive services to 14-year old girls without notifying their parents, and that $94 \%$ would do so for 17 -year old girls. Id.

105. Harris v. McRae, 448 U.S. 297, 318 (1980).

106. Maher v. Roe, 432 U.S. 464, $469-70$ (1977).

107. Harris v. McRae, 448 U.S. at 337 (Brennan, J., dissenting) (quoting Frost \& Frost Trucking Co. v. Railroad Comm'n, 271 U.S. 583, 593-94 (1926)); see Sherbert v. Verner, 374 U.S. 398, 406 (1963).

108. Cf. Perry v. Sinderman, 408 U.S. 593, 597 (1972); Sherbert v. Verner, 374 U.S. 398, 406 (1963) ("to condition the availability of benefits upon this appellant's willingness to violate a cardinal principle of her religious faith effectively penalizes the free exercise of her constitutional liberties").

109. See Perry v. Sinderman, 408 U.S. 593, 597 (1972) (providing a list of areas to which the prohibition against denial of benefits has been applied). 
which motivated Congress to enact and amend Title $X$ suggests that, in the view of the legislature, these alternatives are not viable. ${ }^{110}$

\section{Governmental Interests.}

Statutes and regulations that burden fundamental constitutional rights typically may be upheld if they serve a "compelling state interest." Such statutes and regulations must be narrowly drawn to reflect "only the legitimate state interests at stake."111 In the area of minors' fundamental rights, however, the Supreme Court has developed a less rigorous variation of the compelling state interest test. Under this modified test, restrictions on minors' privacy rights will be upheld if they serve any "significant state interest ... that it is not present in the case of an adult." 112

The cases that require that the state interest be only "significant" rather than "compelling," under this lesser standard of scrutiny, fail to articulate the corresponding degree to which the restriction must serve the interest. Rather, they require only that the restriction "serve" the state interest, without elaborating on the extent to which an otherwise burdensome regulation must satisfy this requirement. ${ }^{113}$ For the purposes of this note, it is assumed that the less rigorous variation of the state interest standard where minors are involved implies a corresponding leniency in the strength of the relationship needed to further the interest. Therefore, to withstand constitutional scrutiny, a regulation burdening minors' fundamental rights probably would not have to be "necessary" to achieve the significant state interest. The fundamental nature of the minor's privacy right, on the other hand, requires that it satisfy considerably more than a mere "rational relationship" test.

The more appropriate standard in these instances arguably bears a closer resemblance to the intermediate level of scrutiny that the Supreme

110. Indeed, had non-Title $X$ contraceptive sources been regarded as a viable and effective alter. native, the teenage pregnancy rate would not have risen to epidemic proportions, thereby creating the kind of emergency to which Congress was responding. See supra note 29-30 and accompanying text.

111. Roe v. Wade, 410 U.S. 113, 155 (1973).

112. Planned Parenthood v. Danforth, 428 U.S. 52, 75 (1976); see also Carey, 431 U.S. at 693 n.15 (citations omitted):

Such lesser scrutiny is appropriate both because of the State's greater latitude to regulate the conduct of children,. . . and because the right of privacy implicated here is "the interest in independence in making certain kinds of important decisions," . . . and the law has generally regarded minors as having a lesser capability for making important decisions.

113. See Carey, 431 U.S. at 693 (prohibiting the distribution of contraceptives to minors does not serve a significant state interest); Planned Parenthood v. Danforth, 428 U.S. at 75 (requiring consent of a parent as a condition for an abortion by an unmarried minor does not serve a significant state interest). 
Court has carved out in gender classification cases. ${ }^{114}$ Under this standard, which requires a showing of an important state interest, the regulation must satisfy a "substantial relationship" test.115 Accordingly, the DHHS regulation must be at least substantially related to a significant state interest if the interest exists exclusively where minors are involved. If, on the other hand, an identical state interest exists with respect to adults as well, the regulation must be necessary to achieve a compelling state interest. If minority is irrelevant to the state's legitimate goals, then it simply cannot serve as a rationale to limit constitutional rights.

This note will examine three state interests that exist only when minors are involved and which, therefore, need only be "significant": (1) protecting the welfare of minors; (2) protecting interests related to parental involvement; and (3) protecting the morality of minors. In addition, the note will consider the state interests in the health of its citizens and in allocating scarce financial resources, both of which apply to adults as well as minors, and must therefore be "compelling."

1. Protecting the Welfare of Minors. The state's interest in protecting the welfare of its young people is well-recognized. ${ }^{116}$ Exercising its powers to tax and spend and to regulate commerce, the federal government may also act to promote health and welfare. ${ }^{117}$ The protective notion of the state as parens patriae is based in large part upon the doctrine of capacity which assumes that minors are unable to understand fully and consent to the consequences of certain decisions. ${ }^{118}$ In the interests of protecting a minor against her own immature and imprudent decisions, the state may impose considerable restraints. Additionally, the

114. See, e.g., Craig v. Boren, 429 U.S. 190, 197 (1976) ("classifications by gender must serve important governmental objectives and must be substantially related to achievement of those objectives").

115. Id. Compare Michael M. v. Sonoma County Super. Ct., 450 U.S. 464 (1981), in which the Supreme Court applied the "substantial relationship" test in upholding the constitutionality of a state statute criminalizing the act of sexual intercourse with a female under the age of 18 . Aithough Michael $M$. was resolved on gender discrimination grounds, in that females were not subject to criminal prosecution for engaging in sexual activity with underage males, the case nevertheless reflects the Court's unwillingness to require a higher degree of scrutiny where the sexual activity of minors is at issue. Even Justice Brennan, in his dissenting opinion, conceded that regulating the sexual activity of minors by threat of criminal prosecution might be permissible as long as it is achieved in a gender-neutral way. Id. at 493-94. See also Carey, 431 U.S. at 705 (Powell, J., concurring in part and dissenting in part) ("There is . . . no justification for subjecting restrictions on the sexual activity of the young to heightened judicial review.").

116. See, e.g., Belloti v. Baird, 443 U.S. 622, 635 (1979) ("[T]he State is entitled to adjust its legal system to account for children's vulnerability and their needs for 'concern, . . . sympathy, and . . . paternal attention.' ") (quoting Meheiver v. Pennsylvania, 403 U.S. 528 (1971)).

117. See supra note 65 .

118. See Planned Parenthood v. Danforth, 428 U.S. at 72 ("Certain decisions are considered by the State to be outside the scope of a minor's ability to act in his own best interest or in the interest of the public. . . ."). See generally Note, supra note 78, at 1220-23. 
state's interest in protecting the welfare of minors encompasses the minor's health and the nature of the contraceptive decision.

As presently drafted, the DHHS regulation is unconstitutional insofar as it seeks to protect all minors from their presumptively immature decisions. Courts have developed a "mature minor exception" to traditional judicial deference to parental authority because some minors are mature enough to understand the nature and implications of their decisions. ${ }^{119}$ The exception has developed most notably in relation to parental consent requirements for medical treatment of minors. ${ }^{120}$ Under the "mature minor exception," a minor seeking medical care may bypass the need to obtain parental consent if she can convince a court that she is sufficiently mature to act in her best interests, and thus, to make an independent judgment to consent to treatment.121 A judicial determination of maturity provides an alternative authorization for a minor to engage in a desired activity, ${ }^{122}$ even in the absence of parental consent. As such, a finding of maturity on the part of the minor satisfies the state's interest in eliminating the dangers incident to immature decisionmaking.

This distinction between mature and immature minors is firmly rooted in the Supreme Court's treatment of the right of privacy. Indeed, each of the Court's abortion decisions involving minors carefully delineates the right of privacy according to the maturity of the parties seeking

119. As one commentator has noted, "the evolution of exceptions to the parental consent requirement reflects an increasing sensitivity to the child as a person . . . Note, Parental Consent Requirements and Privacy Rights of Minors: The Contraceptive Controversy, 88 HARV. L. REv. 1001, 1003 (1975). For a discussion of the three major exceptions-emergency, emancipation, and maturity-that have developed in response to parental consent requirement, see generally $i d$.

120. Applicability of the "mature minor rule" depends upon "an analysis of the nature of the [medical procedure], its likely benefit, and the capacity of the particular minor to understand fully what the . . procedure involves." Baird v. Attoruey General, 371 Mass. 741, 754, 360 N.E.2d 288, 295 (1977). There are, however, some difficulties in applying the rule. See Bellotti v. Baird, 443 U.S. at 643 n.23 ("it [is] difficult to define, let alone determine, maturity"). One commentator has suggested that sexual activity accompanied by an awareness of the importance of contraception may, in itself, be a sign of sufficient maturity to make contraceptive decisions. Hofmann, Consent and Confidentiality and Their Legal and Ethical Implications for Adolescent Medicine, in MEDICAL CARE OF THE ADOLESCENT 42, 51 (3d ed. 1976).

But the opposite conclusion may also justify judicial consent as a protective measure in the minor's best interests:

The sexually active 15-year-old is given access to birth control not out of recognition of his or her mature judgment. Indeed, the less equipped a particular individual is for the burdens of parenthood, the stronger the argument against denying access to contraceptives when we cannot deny aceess to sex.

F. Zimring, The Changing Legal World of Adolescence 63 (1982).

121. See Planned Parenthood v. Danforth, 428 U.S. at 91; Bellotti v. Baird, 443 U.S. at 650.

122. Once a finding has been made that a minor is mature and competent to make an independent decision, it is unconstitutional for judicial authorization to be withheld. See Bellotti v. Baird, 443 U.S. at 651 . 
to forego parental involvement. In Planned Parenthood v. Danforth, 123 which invalidated a parental consent requirement for abortion, the Court emphasized that its holding was not intended to "suggest that every minor, regardless of age or maturity, may give effective consent for termination of her pregnancy."124 Similarly, in Bellotti v. Baird, ${ }^{125}$ the Court reasoned that a parental consent requirement for immature minors seeking abortions might withstand constitutional scrutiny because the state's interest in ensuring parental consultation is enhanced when immature minors are involved. ${ }^{126}$ In H.L. v. Matheson, ${ }^{127}$ the Court indicated that the distinction between maturity and immaturity applied to situations involving notification, as well as consent. Noting that the minor plaintiff in the case failed to allege maturity, the Court upheld a parental notification condition to abortion only insofar as it applied to "immature, dependent minor[s]." 128

In its most recent set of abortion cases, the Court has reaffirmed its commitment to the mature minor exception. ${ }^{129}$ Insisting on the availability of a judicial determination of maturity, Justice Powell, writing for the Court in Planned Parenthood Association v. Ashcroft, emphasized that a finding of maturity provides sufficient authorization for a minor to exercise her right of privacy without confirmation by third parties. ${ }^{130}$ Given this broader right of mature minors to make independent judgments, the Court, in City of Akron v. Akron Center for Reproductive Health, ${ }^{131}$ held unconstitutional "a blanket determination that all minors under [a state-designated age] are too immature to make" a privacy decision. ${ }^{132}$

Despite these judicially recognized differences based on maturity, the DHHS regulation fails to distinguish between mature and immature minors. Rather, it applies generally to "unemancipated minors," which is further defined as "an individual who is age 17 or under and is not,

123. 428 U.S. 52 (1976).

124. Id. at 75 .

125. 443 U.S. 622 (1979).

126. Id. at 640 .

127. 450 U.S. 398 (1981).

128. Id. at 409. As the concurring opinion observed, the limited nature of the Court's holding reserved the separate issue whether the same notification requirement unconstitutionally burdened the privacy right of a mature minor. Id. at 414 (Powell, J., concurring).

129. See City of Akron v. Akron Center for Reproductive Health, 103 S. Ct. 2481, 2491 n.10, 2498 (1983) (adopting the plurality's conclusion in Bellotti that a state must provide an alternative procedure for minors to demonstrate maturity); See also Planned Parenthood Ass'n v. Ashcroft, 103 S. Ct. 2517, 2525 (1983) ("It is clear" that a state must provide such alternative procedures.).

130. 103 S. Ct. 2517,2525 (1983).

131. 103 S. Ct. 2481 (1983).

132. Id. In City of Akron, the threshhold age was as low as 15 years old. $103 \mathrm{~S}$. Ct. at 2498. 
with respect to factors other than age, emancipated under State law."133 To withstand constitutional scrutiny, a burdensome regulation "must be narrowly drawn to express only the legitimate State interests at stake."134 While the regulation is intended to protect minors from their own immature decisions, the regulation applies to many older unemancipated minors between the ages of sixteen and seventeen ${ }^{135}$ who regularly use contraceptive services and would fall within the mature minor exception. As such, the regulation operates as a blanket presumption of immaturity in contravention of the Court's insistence on a case-by-case determination of maturity.

The state may claim that its interest in protecting the welfare of its minors is enhanced considerably given the serious nature of the contraceptive decision and the potential risks associated with teenage preg. nancy and abortion. ${ }^{136}$ To allow the importance of the decision itself to justify greater state interference, however, suggests that the state has a corresponding interest in "maximizing the probability that the decision [will] be made correctly." 137 This view is problematic because many of the reasons posited to justify greater state interference are precisely the same reasons that make the decision so fundamental to the individual's freedom of choice. To permit these same concerns to justify the imposition of state-mandated standards of correctness, 138 therefore, is to undermine the very essence of the right of privacy that guarantees individual autonomy to make personal decisions regarding procreative choices. ${ }^{139}$ Given this conflict, it is doubtful that the state's interest in protecting the welfare of its minors by ensuring "correct" responses to certain decisions rises to the level of a significant state interest.

133. 48 Fed. Reg. 3600,3614 (1983) (to be codified at 42 C.F.R. $\$ 59.5(a)(12)(i)(C))$. The Secretary's proferred reason for failing to distinguish between mature and immature minors is that "a mature minor exception . . . would present major administrative difficulties for projects and enforcement difficulties for the government." Id. at 3611 (Secretary's Preamble).

134. Roe v. Wade, 410 U.S. 113, 155 (1973).

135. In a representative sampling of unemancipated family planning patients, $46 \%$ were 17 years old, $30 \%$ were 16 years old, $17 \%$ were 15 years old, and $7 \%$ were 14 years old or younger. Torres, Forest \& Eisman, supra note 37, at 289-90.

136. See infra notes $169-71$ and accompanying text. To some extent, this argument duplicates the state's concerns with protecting minors from their immature and imprudent decisions. See supra note 120.

137. Planned Parenthood v. Danforth, 428 U.S. at 103 (Stevens, J., concurring in part and dissenting in part).

138. See Note, supra note 78 , at $1235-36$. Indeed, "the very concept of a right of privacy, with its insistence on a neutral state posture towards the ultimate outcome of the decision, seems to deny the state the power to define 'correct' and 'incorrect' choices." Id. at 1236.

139. Eisenstadt v. Baird makes clear that "[i]f the right of privacy means anything, it is the right of the individual, married or single, to be free from unwarranted governmental intrusion into matters [that] so fundamentally affect] a person . . ." 405 U.S. 438, 453 (1972) (emphasis in original). 
Even if the government's interest in ensuring a "correct" result were regarded as valid, and even if the regulation were not strikingly underinclusive as a health measure, it is nevertheless doubtful that the DHHS regulation requiring parental involvement and the purported health goal are correlated. In light of the statistical likelihood of increased pregnancy and abortion among teenagers under the current DHHS regulation, ${ }^{140}$ sexually active minors who seek contraceptive protection may be doing more to protect their own welfare than is the government. Thus, the regulation is not even substantially related to the state's goal of protecting the welfare of its minors.

The DHHS regulation arguably is intended to further the state's interest in protecting the health of its minors, without reference to the maturity of their decisions. Because this health interest is present where both adults and minors are involved, however, it must qualify as a "compelling," rather than a merely "significant," state interest. The state's interest in the health of its citizens arguably satisfies this test. ${ }^{141}$ It is not entirely clear, however, how a regulation that applies only to minors may be said to be "necessary" to further the valid state interests at stake. Indeed, the regulation is grossly underinclusive for failing to apply comparable safeguards to adult women using equally hazardous contraceptives. ${ }^{142}$ Limiting the regulation's application to minor females suggests the pretextual nature of the state's interest in protecting the health of minors.

2. Interests Related to Parental Involvement. Parental notification requirements reflect the state's interest in ensuring that principal family members take part in the child's contraceptive decisionmaking process. The DHHS regulation, therefore, might be justified as an effort to engage sexually active minors and their parents in a meaningful dialogue to advance the following goals: (1) protecting parental sovereignty; (2) encouraging a carefully reasoned decision by the minor through the

140. See supra text accompanying notes 49-51. The consequences that the DHHS regulation may have on health are discussed separately because the state's interest in citizens' health should apply to both adults and minors. See infra text accompanying notes 162-72.

141. See infra notes $\mathbf{1 6 2 - 7 0}$ and accompanying text.

142. The health risks associated with prescription contraceptives are significantly higher for older women than for teenagers. The mortality rate for the pill, for example, is 28.2 times higher for nonsmoking women between the ages of 35-39 than for nonsmoking females between the ages of 1519 , and 64 times greater for women aged $40-44$. Similarly, the risks associated with the pill for smoking women are 21.5 times greater between the ages of 35-39, and 49 times greater between the ages of 40-44, than for their smoking counterparts aged 15-19. Thus, in light of the relative health risks for women in various age groups, the DHHS can hardly justify its focus on the group with the lowest risk in the absence of comparable safeguards for the older group that is exposed to greater danger. ALAN GUTTMACHER INST., supra note 21, at 35. 
contribution of parental experience, knowledge, and guidance; or (3) promoting positive family communication in general.

The legitimacy of either of the first two goals depends on the extent to which parental involvement amounts to control of the outcome of the minor's privacy decision. ${ }^{143}$ Protecting parental sovereignty and allowing parents to forbid their children's access to and use of contraceptives in order to mandate abstinence is tantamount to authorizing the kind of parental veto power that the Court repeatedly has denounced. ${ }^{144}$ This interest, therefore, cannot be deemed "significant." Encouraging parental input in a counseling capacity, on the other hand, may be a permissible goal, ${ }^{145}$ as long as it does not ultimately substitute the parent's choice for the child's. Similarly, the goal of promoting positive family communication arguably appears to be significant.

The extent to which state-mandated notification actually serves either significant goal of promoting intrafamily communication or improving the quality of the minor's decisional framework, however, is questionable. A primary purpose of Title $\mathrm{X}$ clinics is to educate patients, particularly minors, about birth control methods, and the responsibilities and consequences of being sexually active. ${ }^{146}$ In light of the reality that many minors will not discuss their contraceptive decision with their parents or other adults, ${ }^{147}$ the educative practices which Title X clinics em-

143. But cf. Note, supra note 78, at 1235-36 (arguing that even state efforts to assure that minors make well-reasoned contraceptive decisions are improper because they presume "that the quality of such choices can be measured against an objective and ascertainable standard").

144. See Belloti v. Baird, 443 U.S. at $643-44$ (if state requires a minor to obtain parental consent, procedure must not amount to an "absolute, and possibly arbitrary, veto"); Planned Parenthood v. Danforth, 428 U.S. at 73-74 (states lack the constitutional authority to give a third party an absolute veto over the decision of the physician and his patient). Even if this were a permissible goal, however, studies consistently demonstrate that neither parental restrictions nor the unavailability of contraceptives significantly deters teenage sexual activity. See supra note 46.

145. Cf. Doe v. Irwin, 615 F.2d 1162, 1169 (6th Cir.), cert. denied, 449 U.S. 829 (1980) (although parents understandably are concerned about their adolescents' sexual activity and contraceptive use, their interest does not rise to the level of warranting constitutional protection).

146. The practices of a publicly operated family planning clinic in Lansing, Michigan may serve as an illustration. Before contraceptives are dispensed, minors must participate in at least one weekly "rap session" conducted by the center's counseling staff. The sessions deal with factual issues about birth control methods, and are intended to stimulate discussion about nonmedical aspects of teenage sexuality as well. A complete medical history of the minor is required in order to detect medical problems which might be aggravated by a particular contraceptive. If, after a physical exam, no medical problems appear, a three-month supply of oral contraceptives ordinarily will be provided, if this is the patient's preference. If the patient returns for an additional supply of pills, another physical exam will be made and the physieian will inquire about any contraindicative symptoms. A physician always makes the final evaluation about whether a minor should receive a particular contraceptive. Doe v. Irwin, 615 F.2d 1162, 1163-64 (6th Cir.), cert. denied, 449 U.S. 829 (1980).

147. Most clinics stress the desirability of communicating with parents on a voluntary basis about the decision to be sexually active. Id. at 1163 . 
ploy ${ }^{148}$ are designed to ensure that the minor's decision is reasonably well-informed and poses no significant health risks. ${ }^{149}$ It seems unlikely, in most cases, that lay parental input can materially supplement expert medical information.

Proponents of family participation argue that decisions involving teenage sexual activity, contraception, abortion, and pregnancy involve additional factors "much more profound than a mere medical judgment" 150 that a parent is best suited to address. Although there is considerable merit to this argument, it is premised on an assumption that parents will respond rationally and in a helpful manner to the news of the child's sexual activity. In reality, parents frequently do not respond in a manner that contributes meaningfully to the minor's decision. ${ }^{151}$ Moreover, by impersonally notifying parents ${ }^{152}$ only after the child has carried out her decision to obtain contraceptives, and, in many instances, after she has become sexually active, the rule draws parents abruptly into the picture without establishing a framework within which to begin meaningful communication. Finally, the fact that the minor already has chosen not to consult her parents may be symptomatic of a deeper psychological schism between the parent and child ${ }^{153}$ that may make constructive parental input unlikely. The probable effect of notification is only to deepen this schism. Seen in this context, the "squeal rule" does

148. See supra note 146.

149. The health considerations inherent in the decision to use contraceptives are discussed infra at notes 162-72 and accompanying text. It is true that the decision to use contraceptives does not require the same kind of complex medical judgment that is usually involved in the decision to have an abortion. Carey v. Population Servs. Int'l, 431 U.S. 678, 699-700 n.25 (1977). Nevertheless, the use of prescription contraceptives requires a medical determination of the suitability of a particular method and the dosage and size to be prescribed, based on an evaluation of the individual patient.

150. Planned Parenthood v. Danforth, 428 U.S. at 104 (Stevens, J., concurring in part and dissenting in part).

151. Because of the sensitive moral and religious issues involved in the knowledge that an adolescent daughter is sexually active, a parent may often react emotionally rather than rationally. There are numerous instances of parents responding to such knowledge in a manner that is not consistent with the child's best interest. See, e.g., Baird v. Bellotti, 450 F. Supp. 997, 1001 (D. Mass. 1978) (some parents will insist on an undesired marriage, or in the case of a pregnant minor, on carrying the pregnancy to term as punishment), aff', 443 U.S. 622 (1979); Jolly, Young, and Female, and Outside the Law, in Teenage Women in the Juvenile Justice System: Changing Values 97,102 (1979) ("When a young girl becomes pregnant, many families refuse to allow her back into their home."), quoted in H.L. v. Matheson, 450 U.S. at 438 n.24 (Marshall, J., dissenting); Note, supra note 78 , at $1222-23$ n.42.

152. A notice that the minor has received contraceptives is required to be sent to the parents within 10 working days by certified mail "or other similar form of documentation" in order to verify that it has been received. 42 C.F.R. $\$ 59.5(\mathrm{a})(12)(\mathrm{i})(\mathrm{A})(1983)$.

153. Cf. Poe v. Gerstein, 517 F.2d 787, 793-94 (5th Cir. 1975), aff'd mem., 428 U.S. 901 (1976) ('The fact that the minor became pregnant and sought an abortion contrary to the parents' wishes indicates that whatever control the parent once had over the minor has diminished, if not evaporated entirely."). 
not seem to bear a necessary or even a substantial relation to the promotion of meaningful parent-child communication. ${ }^{154}$

3. Moral Interests. A third state interest existing only when minors are involved is the promotion of the child's morality. State statutes prohibiting fornication, statutory rape, and access to pornography by minors, for example, reflect government's continuing concern with the moral environment of its minor citizens. Similarly, the "squeal rule" may be designed to discourage teenage sexual activity in the interests of majoritarian morality. ${ }^{155}$ There is some question, however, whether the rule actually furthers such an interest. By dispensing contraceptives to minors before parents have been notified, ${ }^{156}$ and by offering to provide "referrals to other sources of prescription contraceptives"157 without parental notification, the DHHS regulation does not directly control whether minors ultimately use contraceptives.

Even if the moral interest were served by the regulation, whether it can be deemed "significant" depends on the scope of the minor's constitutionally protected right of privacy. The Supreme Court repeatedly has declined to consider whether the right of privacy contemplates a right to engage in consensual sexual behavior, ${ }^{158}$ nor has it definitively drawn the boundaries of the state's interest in regulating the sexual conduct of its youth. ${ }^{159}$ Recognition of a right to engage in sexual activity as inferred through the established right to obtain and use contraceptives, ${ }^{160}$ however, renders the state's interest in prohibiting such activity insignificant.

Even assuming no constitutionally protected right to engage in nonmarital sexual activity exists, evidence compiled by social scientists conclusively demonstrates that placing restrictions on contraceptive availability will not, in the final analysis, deter adolescent sexual activ-

154. The lines of communication existing within a family "must depend on the quality of emotional attachments within the family, and not on legal patterns imposed by the State." H.L. v. Matheson, 450 U.S. at 437 n.22 (Marshall, J., dissenting). A majority of the Supreme Court has conceded this to be true in its rejection of spousal consent requirements for abortion: "[I]t is difficult to believe that the goal of fostering mutuality and trust in a marriage, and of strengthening the marital relationship and the marriage institution, will be achieved by giving the husband a veto power. .. ." Planned Parenthood v. Danforth, 428 U.S. at 71.

155. DHHS itself conceded that "encouraging adolescent sexual abstinence" was one of the primary goals of the regulation. Brief for DHHS, supra note 35, at 13.

156. 42 C.F.R. § 59.5(a)(12)(i)(A) (1983). In fact, DHHS chose not to adopt a prior notification requirement out of concern that it would "unduly delay or otherwise restrict access to services for adolescents." 48 Fed. Reg. 3600, 3604 (1983).

157. Brief for DHHS, supra note 35 , at 13 .

158. See, e.g., Carey, 431 U.S. at 694 n.17 (1977) (Supreme Court has not determined whether the Constitution prohibits state statutes regulating private consensual sexual behavior among adults).

159. See supra note 80.

160. See supra notes 74-77 and accompanying text. 
ity. ${ }^{161}$ Thus, whatever significant interest the state may have in regulating teenage sexuality, the "squeal rule" does little to further this interest.

4. Health Interests. The state has an interest in protecting the health of its citizens. ${ }^{162}$ Governmental attempts to regulate the use and distribution of contraceptives typically reffect a concern with regulating the consumption or use of hazardous substances. ${ }^{163}$

It may be argued that the notification requirement furthers this interest either by restricting the use of hazardous substances, or by minimizing the risks incident to their use through parental involvement. However, although the state's interest in protecting the health of its citizens may be compelling, the notification requirement does not further this interest. The ability of lay parents to ensure the proper use of contraceptives is limited, ${ }^{164}$ and, by restricting the availability of affordable contraceptive care, mandatory notification increases the risks incident to sexual activity without contraceptive protection.

Despite the suggestion of DHHS, ${ }^{165}$ the mortality risks associated with teenage use of prescription contraceptives is extremely low. ${ }^{166}$ In fact, the estimated risk of death to teenagers from use of any medicallyaccepted method of birth control is much lower than the same risk from

161. See supra note 46 and accompanying text. See generally Jaffe \& Dryfoos, Ferility Control Services for Adolescents: Access and Utilization, 8 FAM. PLAN. PERSP. 167 (1976); Cutright, The Teenage Sexual Revolution and the Myth of an Abstinent Past, 4 FAM. PLAN. PERSP. 24, $30-31$ (1972).

162. Roe v. Wade, 410 U.S. 113, 162 (1973) ("the state has an important and legitimate interest in preserving and protecting the health of the pregnant woman").

163. See, e.g., Eisenstadt v. Baird, 405 U.S. 438, $450-52$ (1972) (contraceptives as a hazardous substance).

164. See Planned Parenthood Ass'n v. Matheson, 582 F. Supp. 1001,1009 n.8 (D. Utah 1983) (striking down a state statute identical to the "squeal rule" on the basis, inter alia, of a finding that "there is no evidence . . . that the doctors who prescribe contraceptives for minors are performing inadequately their obligation to consider the needs of their patients").

165. DHHS contends that the hazardous nature of prescription contraceptives is suggested by the fact that these drugs or devices have "side effects serious enough to warrant a prescription." Brief for DHHS, supra note 35, at 43 . The reasons for requiring a prescription (and thus, the supervision of a physician) for oral contraceptives, IUDs, and diaphragms, however, are not primarily related to their safety. Rather, determining proper dosages or fit, which vary from individual to individual, in order to ensure the effectiveness of these contraceptives, ALAN GUTTMACHER INST., supra note 21, at 5-7, are the main reasons for requiring supervision.

166. Contrary to popular myth, the pill, which is prescribed to $95 \%$ of the mature minors who choose a prescription contraceptive at Title X clinics, Brief for Planned Parenthood, supra note 23, at 33, carries the lowest risk of death of all contraceptives among nonsmoking teenagers. The estimated annual numbers of deaths associated with the following methods of birth control per 100,000 teenage girls ages $15-19$ are as follows:

$\begin{array}{lc}\text { Pill/nonsmoker } & .5 / 100,000 \\ \text { Pill/smoker } & 2.4 \\ \text { IUD } & 1.3 \\ \text { Diaphragm } & 1.9\end{array}$


unintended pregnancy. ${ }^{167}$ Because contraceptive failure rates tend to be higher among teenagers and low-income women generally, ${ }^{168}$ it is especially important that these groups have affordable access to effective methods.

Teenage pregnancy and childbirth, by contrast, pose significant risks to the national health, both because of their impact on the physical and psychological health of the teenage mothers and because their offspring suffer a "higher incidence of low birth weight; . . . a higher frequency of developmental disabilities; [and] higher infant mortality and morbidity."169 Moreover, because almost ninety-six percent of unmarried adolescents who give birth choose to keep their babies, ${ }^{170}$ the infants may face an emotional, social, and economic environment which is inhospitable to healthy development. ${ }^{171}$

Thus, by restricting the availability of relatively nonhazardous prescription contraceptives and by increasing the likelihood of teenage pregnancy ${ }^{172}$ with its attendant harms, the DHHS regulation actually defeats the governmental interest in the health of sexually active women.

5. Fiscal Interests. The "squeal rule"'s redefinition of economic eligibility for Title $\mathrm{X}$ services may be justified by the governmental interest in allocating "scarce Federal dollars" to those low-income families

Alan GUTTMACHER INST., supra note 21, at 35 (Fig. 15).

167. Over 7 per 100,000 teenagers ages $15-19$ die each year as a consequence of unintended pregnancy and childbirth when no method is used. AlAN GUTTMACHER INST., supra note 21, at 35.

168. Women under the age of 22 are approximately two times more likely to experience contraceptive failure (and unintended pregnancy) as women over 30. Id. at 30 (Fig. 13). This may be attributable to a number of factors, including less experience with contraceptive use, greater fertility, and more frequent intercourse. Socio-economic status, in addition to age, also seems to bear some relation to the rate of contraceptive failure. Women with annual family incomes of under $\$ 10,000$ using prescription methods are two times more likely to experience contraceptive failure than those with incomes of over $\$ 15,000$. Id. at 31 .

169. 42 U.S.C. $\S 300 z(a)(5)$ (1982) (congressional findings). The emotional and psychological effects of pregnancy and abortion have been shown to be considerably more traumatic in tcenagers than in adults. See generally Wallerstein, Kurtz \& Bar-Din, Psychological Sequelae of Therapeutic Abortion in Young Unmarried Women, 27 ARCH. GEN. PsyChIATRY 828 (1972). One study indicated that almost $25 \%$ of all female minors who try to commit suicide do so because they are pregnant or at least fear that they are. Teicher, $A$ Solution to the Chronic Problem of Living: Adolescent Attempted Suicide, in CURRENT Issues 1N ADOLESCENT PsYCHIATRY 129, 136 (J. Schoolar cd. 1973).

170. 42 U.S.C. $\S 300 z(a)(6)(B)$ (1982) (congressional finding).

171. In authorizing the Adolescent Family Life Demonstration Projects (Title XX), Congress found that pregnancy and childbirth among unmarried adolescents tended to result in "a decreased likelihood of completing schooling; a greater likelihood that an adolescent marriage will end in divorce; and higher risks of employment and welfare dependency." 42 U.S.C. $\$ 300 z(a)(5)$ (1982) (congressional finding).

172. See supra note 50 and accompanying text. 
who are truly in need. ${ }^{173}$ Whatever interest the government may have in ensuring priority care for low-income adolescents, however, is undermined by the notification portion of the DHHS regulation, which operates ultimately to discourage these eligible minors from using Title $\mathrm{X}$ services. ${ }^{174}$

Moreover, DHHS seems to ignore the soaring costs associated with teenage pregnancies that will result from deterring contraceptive use. ${ }^{175}$ It is estimated that almost half of all teenagers who become pregnant carry their babies to term. ${ }^{176}$ Only four percent of these mothers arrange for an adoptive family to care for the baby ${ }^{177}$ and those who choose to raise the child in their household incur tremendous welfare costs for the government. ${ }^{178}$ In the long run, DHHS' attempts to cut back on the cost of federally subsidized contraceptive services will result in far greater economic and social costs as a result of increased teenage pregnancies and births.

\section{CONCLUSION}

The Supreme Court has not addressed the constitutionality of mandatory parental notification as a condition to the distribution of contraceptives to unemancipated minors. Despite a judicial reluctance to construe the privacy rights of minors too broadly, the minor's interest in obtaining affordable and effective contraceptive services seems to override any concurrent concerns of the government. The "squeal rule" seriously impinges on these privacy interests. By sweeping too broadly in applying to mature as well as immature minors, and by failing to anticipate the inevitable consequences of its operation, the "squeal rule" steps outside the bounds of constitutionally acceptable regulation.

Brenda D. Hofman

173. 48 Fed. Reg. 3600, 3613 (1983).

174. DHHS observes that low-income minors voluntarily inform their parents of their contraceptive practices more often than do their middle class counterparts. Id. This finding, however, is based on a small sampling of clinics and does not conclusively refute the overwhelming evidence that minors of all classes would be deterred by mandatory notification policies. See supra note 46 and accompanying text.

175. See supra notes $50-51$ and accompanying text.

176. 42 U.S.C. $\S 300 z(a)(1)$ (1982) (congressional findings).

177. 42 U.S.C. $\$ 300 z(a)(6)(B)$ (1982) (congressional findings).

178. The estimated cost of raising one child in an average income family to age 22 (excluding college costs) is $\$ 215,000$. AlAN GUTTMACHER INST., supra note 21 , at 24 . In the case of adolescent parenthood, these costs fall largely on government welfare programs. In 1978, $\$ 4.65$ billion in welfare went to households where an adolescent had a child. 124 CoNG. REC. 35,621 (1978) (statement of Rep. Rogers). 

. 